CASSOWARY volume 3 (2): 153 - 191

ISSN : 2614-8900

E-ISSN : 2622-6545

Program Pascasarjana Universitas Papua, https://pasca.unipa.ac.id/

\title{
Strategi Pengelolaan Taman Wisata Alam Gunung Meja melalui Penataan Kawasan
}

Strategy of Gunung Meja Natural Park Management by region arrangement

Daniel Leonard, Anton Silas Sinery*, Jacob Manusawai

Program Studi Magister Ilmu Lingkungan, Program Pascasarjana UNIPA, Manokwari, 98314, Indonesia

*Email: anton_sineri@yahoo.com

ABSTRACT: The purpose of this research is to formulate management strategies related to the condition and potential of the park. The results showed that land cover of Gunung Meja natural tourism park dominated by natural forest $(77.5 \%)$, followed by plantations forest $(11.7 \%)$, the former garden area (5.6\%), gardens $(3.4 \%)$ and open land, electricity network, tower and street with percent smaller extent. Potential natural forest vegetation is very high, includes 159 species of trees (186 individuals/ha, high diversity indeck), 149 species of poles (867 individuals / ha, medium diversity indeck), 164 species of saplings (3,904 individuals / ha, medium diversity indeck) and 177 species of seedlings (32,300 individuals / ha, medium diversity indeck) with the total of species is 223 , as well as forest vegetation plants, medicinal plants and farm / plantation vegetation. The diversity of wildlife species include 15 species of mammals $(2$ species protected), 35 species of birds (12 species protected), 21 other species (8 lizards, 3 amphibia, 9 snakes and 1 turtles) and 14 species of insects (1 species protected). Potential support includes Japanese monument, caves, water and social communities. Utilization of the region has not done so well that affect the area as a result of the existence of agricultural activities, logging and utilities. Referral management includes policies (policies that embody accommodate all interests through the zoning system by protected zone, farm exploit zone and buffer zone).

Keyword: strategies, zoning area, natural tourism park, Gunung Meja

ABSTRAK: Taman Wisata Alam Gunung Meja kawasan konservasi yang memiliki keanekaragaman jenis flora, fauna, ekosistem maupun jasa linkungan yang potensial dan sebagai tandon air bagi kota Manokwari. Kawasan hutan ini belum memiliki perencanaan pengelolaan aktual yang mempertimbangkan kondisi dan potensi, sehingga perlu dilakukan pengelolaan terkait kondisi dan potensi kawasan. Tujuan penelitian ini adalah untuk mengetahui kondisi dan potensi kawasan, pemanfaatan kawasan untuk selanjutnya menyusun strategi pengelolaan terkait penataan blok pengelolaan. Berdasarkan hasil penelitian diketahui bahwa tutupan lahan didominasi hutan alam $(77,5 \%)$, diikuti hutan tanaman $(11,7 \%)$, areal bekas kebun $(5,6 \%)$, kebun $(3,4 \%)$ dan tutupan lain berupa tanah terbuka, jaringan listrik dan tower dan jalan dengan persentase luasannya lebih kecil. Potensi vegetasi hutan alam sangat tinggi, mencakup 159 jenis tingkat pohon (186 individu/ha, keanekaragaman jenis tinggi), 149 jenis tingkat tiang (867individu/ha, keanekaragaman jenis sedang), 164 jenis tingkat pancang (3.904 
individu/ha, keanekaragaman jenis sedang) dan 177 jenis tingkat semai (32.300 individu/ha, keanekaragaman jenis sedang) dengan jumlah jenis keseluruhan 223 jenis (areal 100 ha) demikian juga vegetasi hutan tanaman, tumbuhan obat dan vegetasi pertanian/perkebunan. Potensi keanekaragaman jenis satwa liar mencakup 15jenis mamalia ( 2 jenis dilindungi), 35 jenis burung (12 jenis dilindungi), 21 jenis herpetofaona ( 8 kadal, 3 ampibia, 9 jenis ular dan 1 jenis kura-kura) dan 14 jenis insekta ( 1 jenis dilindungi). Potensi penunjang meliputi tugu jepang, goa, air dan kondisi sosial masyarakat. Pemanfaatan kawasan TWA Gunung Meja sesuai fungsinya belum dilakukan secara baik sehingga mempengaruhi eksistensi kawasan akibat kegiatan pertanian, penebangan hutan, pembangunan fasilitas umum seperti jaringan listrik, sarana telekomunikasi dan pembuangan sampah. Arahan pengelolaan yang dapat dilakukan adalah mewujudkan kebijakan baru terkait luas kawasan yang lebih mengakomodir semua kepentingan melalui sistem blok yang mencakup blok perlindungan, blok pemanfaatan dan blok penyangga (buffer zona).

Keywords: Strategi, Penataan Kawasan, Taman Wisata Alam, Gunung Meja

\section{PENDAHULUAN}

Pelaksanaan pembangunan telah menghasilkan kemajuan dalam segenap aspek kehidupan bangsa yang tercermin melalui sarana dan prasarana fisik, dan semakin terpenujinya kebutuhan pokok rakyat sehingga telah meletakkan landasan yang kuat untuk memasuki tahap selanjutnya. Disamping peluang yang dimiliki, banyak tantangan yang akan dihadapi dalam melaksanakan Pembangunan. Tantangan tersebut disebabkan adanya perubahan tuntutan dan keinginan masyarakat, baik karena perubahan kualitas hidup akibat kemajuan pembangunan maupun pengaruh perkembangan teknologi dan globalisasi.

Dalam melaksanakan pembangunan, penggunaan sumber daya alam dilakukan secara terencana, rasional, optimal, bertanggung jawab, dan sesuai dengan kemampuan daya dukungnya, dengan mengutamakan sebesar-besar kemakmuran rakyat, serta dengan memperhatikan kelestarian fungsi dan keseimbangan lingkungan hidup serta keanekaragaman hayati guna mewujudkan pembangunan yang berkelanjutan.
Kebijakan pengelolaan sumber daya alam khususnya konservasi sumber daya alam hayati di Indonesia diatur dalam Undang-Undang Nomor 5 tahun 1990 (tentang Konservasi Sumber daya Alam Hayati dan Ekosistemnya) yang mencakup pengawetan sistem penyanggah kehidupan, perlindungan sumber daya alam dan ekosistemnya dan pemanfaatan secara lestari sumber daya alam dane kosistemnya. Kebijakan tersebut dijabarkan lebih lanjut dalam sejumlah peraturan seperti halnya PP Nomor 28 tahun 2011 tentang Pengelolaan Kawasan Suaka Alam/KSA dan Kawasan Pelestarian Alam/KPA) dan sejumlah aturan lainnya atau Keputusan Presiden Nomor 32 tahun 1999 tentang Pengelolaan Kawasan Lindung.

Peraturan perundang-undangan tersebut bertujuan untuk mengarahkan pengelolaan sumber daya alam baik dalam hubungannya dengan lingkungan (ekologis) maupun meningkatkan kesejahteraan masyarakat melalui pembangunan. Namun kenyataan menunjukkan bahwa kegagalan pengelolaan sumber daya alam disebabkan karena kurangnya perhatian terhadap lingkungan. Di sisi lain berhasilnya 
pengelolaan unit pengelo-laan (kawasan konservasi, kawasan lindung atau juga hutan produksi) disebabkan karena adanya campur tangan manusia untuk mempertahankan dan meningkatkan kualitas unit manajemen. Sementara itu, desakan kebutuhan akan lahan bagi masyarakat sekitar lokasi kegiatan merupakan suatu hal yang mutlak dipertimbangkan dalam menunjang kelangsungan kegiatan pengelolaan (Sinery dkk, 2013).

Kenyataan menunjukkan bahwa ancaman tidak muncul saja terhadap kawasan-kawasan yang dianggap sebagai kawasan yang telah ditetapkan sebagai kawasan eksploitasi saja, akan tetapi juga tertuju kepada kawasankawasan yang ditetapkan dan ditunjuk sebagai kawasan konservasi atau kawasan lindung. Ancaman tersebut disamping disebabkan oleh pertambahan penduduk, juga oleh perusakan langsung, konversi kawasan dan penangkapan satwa secara berlebihan. Pengelolaan sumber daya alam melalui pemanfaatan lahan, tumbuhan dan satwa liar serta komponen lingkungan lainnya di hutan tropis tidak lagi memperhatikan aspek-aspek kelestarian, sehingga menimbulkan ancaman kepunahan terhadap komponen lingkungan (Robinson dan Redford, 1994; Robinson dan Bodmer, 1999 dalam Pattiselanno, 2007). Menurut Sinery (2013) telah terjadi pergeseran pola pemanfaatan sumber daya alam oleh masyarakat sekitar hutan dari pola pemenuhan kebutuhan dasar (basic need) menjadi keinginan meningkatkan ekonomi (economic needs). Pola pemanfaatan tersebut dilakukan melalui konversi kawasan hutan untuk pengembangan berbagai kegiatan usaha terutama di kawasan-kawasan pelestarian alam seperti halnya Taman Wisata Gunung Meja di Kabupaten Manokwari Provinsi Papua Barat.
Hutan Gunung Meja merupakan salah satu kawasan pelestarian alam berstatus taman wisata alam di wilayah Provinsi Papua Barat yang ditetapkan berdasarkan Surat Keputusan Menteri Kehutanan Nomor: 91/Menhut-II2012 dengan luas wilayah 462,16 Ha. Kawasan ini berada pada 16 - 177 m dpl dan merupakan laboratorium alam yang menyimpan keanekaragaman jenis flora maupun fauna yang cukup tinggi dan sebagai tandon air bagi kota Manokwari (Leppe dan Tokede, 2004; Sinery, 2006). Sesuai hasil survey spasial WWF tahun 2002 diketahui bahwa terdapat 5 mata air di dalam kawasan ini sedangkan berdasarkan Laporan Perusahaan Daerah Air Minum Kabupaten Manokwari, ada 12 mata air yang menjadi sumber pasokan air bagi masyarakat Kota Manokwari dan 7 diantaranya terdapat di dalam dan sekitar hutan ini (Liborang, 2004).

Kawasan Hutan Wisata Gunung Meja berbatasan langsung dengan pemukiman penduduk di sekeliling maupun di dalam kawasan. Di tengah kawasan ini terdapat akses jalan yang membentang dari arah utara-selatan serta menuju sebelah barat. Kondisi demikian menyebabakan kawasan hutan ini mudah diakses dan rawan terhadap pemanfaatan sumber daya alam (pengambilan kayu bakar, bahan bangunan, perburuan satwa) dan konversi kawasan (pembukaan lahan untuk ladang/kebun). Menurut Liborang (2004); Lekitoo, dkk, (2008) bahwa meningkatnya jumlah penduduk dan keterbatasan lahan menyebabkan meningkatnya pembukaan sebagian wilayah Hutan Wisata Gunung Meja untuk areal perladangan. Ancaman utama kerusakan kawasan Taman Wisata Alam Gunung Meja adalah akibat aktivitas masyarakat. 
Menurut Ohuiwutun (1995) dalam Sinery (2006) kerusakan hutan Taman Wisata Gunung Meja sebagai akibat aktifitas masyarakat di sekitarnya mencapai 8,9 ha. Menurut Apriani (2003), pemanfaatan lahan Hutan Taman Wisata Gunung Meja tahun 2002 sebesar 39,42 ha dengan intensitas $8,6 \%$, mencakup perladangan 35,32 ha (intensitas 7,68\%), penebangan 0,81 ha (intensitas $0,18 \%$ ), bekas perladangan 0,34 ha (intensitas 0,09\%) dan penggunaan lain 2,95 ha (intensitas $0,64 \%$ ). Kondisi ini mengakibatkan degradasi kawasan hutan yang menjadi potensi wisata unggulan dan fragmentasi habitat berbagai jenis satwa liar. Selanjutnya menurut Kondororik (2012), ada 30 lokasi tumpukan sampah dengan luas areal tumpukan $2.054 \mathrm{~m}^{2}$ atau $0,2054 \mathrm{Ha}$

Seiring dengan pertambahan penduduk, pertumbuhan ekonomi dan industrial, maka tekanan terhadap sumber daya alam menjadi semakin besar karena tingkat kebutuhan dan kepentingan terhadap sumber daya alam yang semakin tinggi. Hal ini dapat dilihat dari berbagai kenyataan betapa pembukaan hutan dan eksploitasi sumber daya alam lainnya dari tahun ke tahun bukannya menurun, akan tetapi semakin meningkat. Dengan demikian tentunya kawasan-kawasan tempat eksploitasi semakin terancam habis, sementara suksesi sumber daya alam yang dapat diperbaharui yang telah dieksploitasi membutuhkan waktu lama untuk dapat diperbaharui kembali.

Kawasan Hutan Wisata Gunung Meja sejak penetapannya dikelola oleh Balai Konservasi Sumber Daya Alam Barat melalui Seksi Konservasi Wilayah I Manokwari. Sejauh ini berbagai upaya telah dilakukan terkait perlindungan, pelestarian dan pemanfaatan hutan ini, namun ancaman terhadap eksistensi kawasan terus berlangsung. Di sisi lain, sejauh ini belum ada perencanaan terkait sistem zonasi atau blok pengelolaan yang mempertimbangkan semua komponen kawasan, sehingga dinilai perlu dilakukan penelitian terkait kondisi tersebut.

Berdasarkan uraian permasalahan diatas, maka dirumuskan beberapa pertanyaan penelitian sebagai berikut:

1 Bagaimana kondisi umum kawasan Taman Wisata Alam Gunung Meja berdasarkan kondisi fisik, biologi dan sosial.

2 Bagaimana arahan yang dapat dilakukan guna mewujudkan tujuan pengelolaan sesuai fungsi kawasan khusunya terkait blok atau sistem zonasi (zoning system).

Penelitian ini bertujuan untuk mengidentifikasi kondisi atau potensi kawasan Hutan Wisata Gunung Meja untuk selanjutnya merumuskan upayaupaya pengelolaan berdasarkan blok pengelolaan sehingga lebih mengoptimalkan keberlangsungan pengelolaan kawasan hutan ini di masa mendatang, dengan rincian tujuan mencakup:

1 Mengetahui kawasan Taman Wisata Alam Gunung Meja berdasarkan kondisi fisik.

2 Mengetahui potensi kawasan yang mencakup potensi keanekeragaman hayati flora dan fauna serta potensi lainnya termasuk kondisi sosial ekonomi dan budaya masyarakat.

3 Mengetahui pemanfaatan kawasan terkait eksistensi sumber daya alam di kawasan berdasarkan sistem ekologi.

4 Merumuskan strategi pengelolaan guna menunjang optimalisasi pengelolaan sesuai fungsi kawasan 


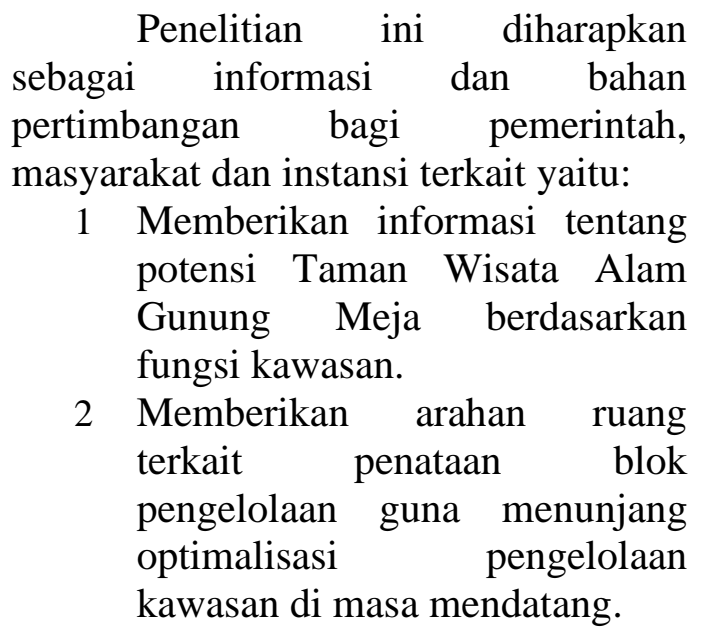

\section{METODE PENELITIAN}

\section{Lokasi dan Waktu Penelitian}

Penelitian ini dilakukan di Kawasan Taman Wisata Gunung Meja Kabupaten Manokwari Provinsi Papua Barat. Secara geografis hutan ini terletak antara $134^{\circ} 03^{\prime} 17^{\prime \prime}$ sampai 13404'05" Bujur Timur dan 0 51'29" sampai 0052'59" Lintang Selatan dengan ketinggian tempat berkisar antara 17-177 m dpl.

Penelitian ini berlangsung selama 6 bulan dan dimulai pada bulan Juni sampai November 2014. Kegiatan penelitian mencakup persiapan penelitian, pelaksanaan pengambilan data dan analisis data yang terdiri atas data primer dan data sekunder.

\section{Alat dan Bahan Penelitian}

Peralatan yang digunakan dalam penelitian ini terdiri atas:

a. Peralatan analisis vegetasi, meliputi Global Positioning System (GPS), clinometer, hagahypsometer, kompas, phi band, parang, tally sheet dan hasil-hasil penelitian terkait potensi flora.

b. Peralatan monitoring satwa liar, meliputi binokuler, kunci identifikasi jenis satwa liar dan peta lokasi penelitian c. Peta kawasan Taman Wisata Alam Gunung Meja (SK Menhut No.91/Menhut-II/2012) tentang Penetapan Kawasan Hutan Taman Wisata Alam Gunung Meja Yang Terletak Di Distrik Manokwari Barat Dan Manokwari Timur, Kabupaten Manokwari, Provinsi Papua Barat Seluas 462,16 (Empat Ratus Enam Puluh Dua Dan Enam Belas Perseratusi Hektar).

d. Peta Digital Rupa Bumi Indonesia skala 1:25 000, Peta Administrasi skala 1:25 000, Peta Tata Batas skala 1:1 000 dan Citra Landsat (liputan tahun 2012).

e. Format isian, untuk pengumpulan informasi dan hasil observasi;

f. Peralatan dokumentasi meliputi photo camera dan vedeo camera, peralatan tulis menulis.

Bahan yang digunakan dalam penelitian berupa kertas koran, alkohol $70 \%$ dan dietil eter /kloroform masingmasing untuk pembuatan spesimen tumbuhan dan satwaliar.

\section{Prosedur Penelitian \\ Kondisi Umum Kawasan}

Untuk mengetahui kondisi
umum kawasan hutan (lokasi penelitian) yang mencakup data kondisi fisik, kondisi biologi dan kondisi sosial, dilakukan pengambilan data primer di lapangan maupun pengambilan data sekunder pada instansi terkait.

\section{Tutupan Lahan}

Data yang digunakan untuk menentukan kondisi tutupan lahan adalah hasil analisis interpretasi dan klasifikasi citra landsat lokasi Taman Wisata Alam Gunung Meja tahun 2012. Pengolahan data citra digital dilakukan dengan tahapan sebagai berikut.

- Data citra digital dari google maps (tahun 2012) dicopy dengan menggunakan metode print screen; 
- Data selanjutnya disimpan dengan tipe Tagged Image File Format (TIFF);

- Dengan bantuan software Global Mapper 8.01 dilakukan penentuan ketepatan letak koordinat dengan memasukkan 4 titik di lapangan sebagai Ground Control Point (GCP);

- Data siap dianalisis dengan software Image Analysis dan setelah Citra Satelit dianalisis dan diklasifikasi

- Data hasil analsis selanjutnya dioverlay dengan peta kawasan Taman Wisata Alam Gunung Meja (SK Menhut No.91 Tahun 2012) untuk mengidentifikasi tipe-tipe tutupan lahan yang terdapat dalam kawasan ini untuk selanjutnya dilakukan verifikasi melalui observasi lapangan.

\section{Potensi Penunjang Pengelolaan Kawasan}

Untuk mengetahui potensi kawasan dalam menunjang pengelolaan fungsi kawasan, dilakukan observasi terhadap potensi penunjang pengelolaan kawasan yang mencakup mata air, tugu jepang, jalan dan goa dan hutan yang mencakup hutan alam dan hutan tanaman. Hasil observasi selanjutnya dipetakan sehingga menjadi pertimbangan dalam penataan blok pengelolaan.

\section{Potensi Keanekaragaman Hayati}

$$
\text { Untuk menilai potensi }
$$

keanekaragaman hayati yang mencakup potensi flora dan fauna, maka dilakukan analisis vegetasi dan inventarisasi jenisjenis satwa liar. Analisis vegetasi dilakukan melalui sampling dengan mengunakan metode Line Plot Sistematyc Sampling pada areal seluas 250 ha. Base line dibuat dengan azimut $180^{\circ}$, azimut jalur $90^{\circ}$. Jarak antar jalur $200 \mathrm{~m}$, jarak antar plot dalam jalur 100 $\mathrm{m}$, jarak antara titik start base line

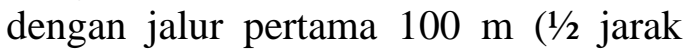
antar jalur) dan jarak antara plot pertama dalam jalur dengan base line 50 meter ( $1 / 2$ jarak antar plot dalam jalur). Jumlah jalur yang dibuat sebanyak 5 jalur, jumlah petak dalam jalur sebanyak 25 petak ukur dengan total petak pengamatan yang dibuat adalah 125 petak ukur masing-masing fase. Pengambilan data mencakup vegetasi semai/seedling (tinggi $\leq 1,5 \mathrm{~cm}$ ) petak 2 $\mathrm{x} 2 \mathrm{~m}$, pancang/sapling (tinggi $>1,5 \mathrm{~cm}$ dan diameter $<10 \mathrm{~cm}$ ) petak $5 \times 5 \mathrm{~m}$, tiang/poles (diameter $10-20 \mathrm{~cm}$ ) petak $10 \mathrm{x} 10 \mathrm{~m}$ dan pohon/trees (diameter > $20 \mathrm{~cm}$ ) petak $20 \times 20 \mathrm{~m}$. satwa liar yang terdapat di dalam kawasan dilakukan secara langsung bersamaan dengan analisis vegetasi. Metode yang digunakan adalah metode jalur/transek dengan sama dengan panjang jalur dalam inventarisasi vegetasi. Pengamatan juga dilakukan melalui jalan koridor di tengah kawasan dari arah selatan - utara dan menuju barat dengan panjang jalur pengamatan 9-10 $\mathrm{km}$. Pengamatan difokuskan pada satwa liar kelas mamalia dan aves, namun tidak terbatas juga untuk satwa liar lainnya (reptil dan amfibi).

\section{Pemanfaatan Kawasan}

Pengamatan pemanfaatan kawasan oleh masyarakat sekitar dilakukan melalui pengamatan langsung dan wawancara terhadap jenis-jenis dan lokasi pemanfaatan. Berdasarkan hasil wawancara, selanjutnya dilakukan pengukuran terhadap lokasi-lokasi dimaksud yang mencakup lokasi kegiatan ladang, penebangan, bekas ladang dan penggunaan lain. Data hasil pengukuran selanjutnya dikomparasikan (ditumpang susun/overlay) dengan hasil analisis citra landsat.

Menurut Liborang (2004), ada 5 keluruhanan yang masyarakatnya 
memanfaatkan kawasan Taman Wisata Alam Gunung Meja yaitu kelurahan Manokwari Timur, Manokwari Barat, Padarni, Pasir Putih dan kelurahan Amban. Sesuai hasil penelitian tersebut, maka kelima kelurahan ini menjadi lokasi pengambilan data soial terkait pemanfaatan. Dari jumlah tersebut empat diantaranya berbatasan langsung dengan kawasan, masing-masing Kelurahan Manokwari Timur, Kelurahan Padarni, Kelurahan Pasir Putih dan Kelurahan Amban. Penentuan responden yang disampling dilakukan secara purposif sesuai kegiatan pemanfaatan kawasan yang mencakup masyarakat pelaku pemanfaatan kawasan dan toko masyarakat dengan jumlah responden sebanyak 185 orang masing-masing kelurahan Manokwari Timur (22 KK), Manokwari Barat (27 KK), Padarni (40 KK), Pasir Putih (36 KK) dan kelurahan Amban (60 KK).

Melalui hasil pengamatan dan wawancara selanjutnya dilakukan pemetaan areal pemanfaatan kawasan dengan menggunakan GPS untuk selanjutnya di tumpang susun (overlay) dengan hasil analisis citra untuk menentukan lokasi dan atau luas arealareal potensial pemanfaatan.

\section{Pengumpulan Data}

Data yang dikumpulkan dalam penelitian ini terdiri atas data primer yaitu data hasil pengamatan dan wawancara dan data sekunder yang diperoleh dari instansi terkait. Data primer yang dikumpulkan terdiri atas:

a. Kondisi umum (iklim, topografi, kelerengan, geologi, tanah, hidrologi dan kondisi sosial)

b. Tutupan lahan

c. Potensi keanekeragaman hayati yang terdiri atas potensi flora dan fauna. d. Potensi pemanfaatan kawasan oleh masyarakat dan atau pihak terkait.

Data sekunder yang dikumpulkan adalah data keadaan umum lokasi penelitian yang mencakup data terkait kondisi fisik (iklim, geologi, tanah, hidrologi) kondisi biologi (potensi vegetasi dan satwa liar) dan kondisi sosial ekonomi dan budaya masyarakat sekitar kawasan.

\section{Analisis Data}

Data hasil observasi dianalisis secara deskriptif kuantitatif dan kualitatif sesuai masing-masing komponen dan ditampilkan secara tabulasi dan gambar (bagan, grafik dan foto).

\section{A. Kondisi umum lokasi penelitian}

Data keadaan umum lokasi penelitian yang mencakup data kondisi fisik, biologi dan sosial akan dianalisis secara tabulasi dan deskriptif.

\section{B. Tutupan lahan}

Untuk memperoleh tipe dan luas penutupan lahan dari interpretasi citra landsat, dilakukan analisis dengan menggunakan metode klasifikasi terbimbing (supervised classification) dan klasifikasi tidak terbimbing (unsepervised classification) dan secara visual (visually classification). Dengan klasifikasi terbimbing bisa dilakukan secara otomatis (outomatic classification) dan secara visual (visually classification).

Hasil klasifikasi visual akan dijadikan dasar penetapan tutupan lahan dalam kawasan. Tipe tutupan lahan dibedakan berdasarkan tutupan petunjuk Badan Planologi Departemen Kehutanan (2001). Analisis sederhana minimal menghasilkan 7 tipe tutupan lahan antara lain hutan sekunder (HS), semak belukar (Sb), Hutan mangrove sekunder (Hm), ekosistem rawa (ER), 
tubuh air (Ta), pemukiman penduduk (Pp) dan Tanah terbuka (Tt). Selanjutnya dengan bantuan pemetaan Sistem Informasi Geografi (SIG) dapat diketahui luas masing-masing tipe penutupan lahan dapat diketahui selisih luas tutupan lahan yang dianalisis. Lebih dari itu perubahan tersebut dapat diprediksi tren perubahan kawasan baik secara kuantitas maupun secara kualitas.

Penilaian kelayakan kawasan berdasarkan aspek potensi lahan sebagai kawasan konservasi (Taman Wisata Alam) adalah pertimbangan aspek ekologis yang didukung oleh peraturan yang berlaku khususnya Peraturan Pemerintah Nomor 28 Tahun 2011 tentang Pengelolaan Kawasan Suaka Alam dan Kawasan Pelestarian Alam.

Analisis hasil tumpang susun dari berbagai peta adalah untuk mendapatkan gambaran umum serta menyeluruh mengenai keadaan wilayah TWA Gunung Meja, terutama penggunaan lahan dan kesesuaiannya dengan fungsi kawasan. Hasil analisis ini juga akan memberikan gambaran fisik lapangan sebenarnya dimana akan diketahui apakah fungsi hutan tersebut masih sesuai atau sudah berubah oleh perkembangan dinamis keadaan sosial ekonomi dan perkembangan wilayah.

\section{Potensi Penunjang Pengelolaan}

Potensi penunjang pengelolaan yang mencakup potensi fisik seperti mata air, tuguh, goa, jalan dan potensi lainnya dianalisis secara deskriptif.

\section{E. Keanekaragaman Hayati}

Kondisi vegetasi di kawasan Taman Wisata Gunung Meja dianalisis dengan menggunakan persamaan Indeks Nilai Penting (INP) menurut MuellerDombois and Ellenberg (1974); Soerianegara dan Indrawan (1983) sebagai berikut.
Kerapatan = Jumlah individu suatu jenis

Jumlah luas plot contoh

Kerapatan Relatif $=$

$\frac{\text { Kerapatan suatu jenis }}{\text { Kerapatan seluruh jenis }} \times 100$

Frekuensi $=$

Jumlah plot ditemukannya suatu jenis

Jumlah seluruh plot contoh

Frekuensi Relatif $=$

Frekuensi suatu jenis x100

Frekuensiseluruh jenis

Dominasi $=$

Jumlah luas bidang dasarsuatu jenis

Luas seluruh plot contoh

Dominasi Relatif $=$

Dominasi suatu jenis $\times 100$

Dominasi seluruh jenis

Luas Bidang Dasar $(\mathrm{LBD})=$

$$
1 / 4 \pi(d / 100)^{2}
$$

Secara khusus untuk vegetasi tingkat tiang dan pohon diperoleh penjumlahan persentasi kerepatan, frekuensi relatif dan dominasi relatif (Indeks Nilai Penting/INP = Kerapatan Relatif + Frekuensi Relatif + Dominasi Relatif). Selanjutnya untuk INP vegetasi tingkat semai dan pancang adalah penjumlahan kerapatan relatif dan frekuensi relatif.

Untuk menentukan tingkat keanekaragaman jenis vegetasi sebagai indikator variasi jenis vegetasi di kawasan, dilakukan analisis keanekaragaman jenis (H') dengan persamaan menurut Shanon dan Wiener (1949) dalam Odum (1993): 
$H^{\prime}=-\sum\left[\frac{n i}{N}\right] \ln \left[\frac{n i}{N}\right]$

Keterangan:

$\mathrm{H}^{\prime}=$ Indeks keanekaragaman (Indeks Shannon-Wiener)

ni $=$ Jumlah individu jenis ke- $n$

$\mathrm{N}=$ Jumlah individu seluruh jenis vegetasi

Untuk jenis-jenis satwa liar yang didata dianalisis secara tabulasi sesuai jenis dan kelas. Jenis-jenis tersebut dikategorikan berdasarkan status perlindungan sesuai UU No.5 Tahun 1990 (tentang Konservasi Sumber Daya Alam Hayati dan Ekosistemnya) dan PP 7 tahun 1999 (tentang Pengawetan Jenis Tumbuhan dan Satwa) serta International Union Conservation Nature and Nature Resourches (IUCN update 2011) dan Convention Interntional Tread Endanger Species (CITES, 2011).

\section{F. Pemanfaatan kawasan}

Data terkait pemanfaatan kawasan oleh masyarakat sekitar maupun kegiatan pembangunan dianalisis secara deskriptif dengan teknik observasi.

\section{G. Penentuan Blok Pengelolaan TWA/Zonasi}

Proses yang dilakukan untuk membuat zonasi yang baru adalah dengan mengoverlaykan peta tutupan vegetasi dan penggunaan lahan yang didapatkan dari interpretasi Citra tahun 2012 dan peta penyebaran flora dan fauna yang bersumber dan peta kawasan. Setelah overlay kemudian dilakukan pendijitasian secara on screen (pendijitasian secara langsung pada monitor komputer) yang akan menampilkan arahan blok atau areal dalam kawasan untuk digunakan sebagai arahan blok pengelolaan.

\section{HASIL DAN PEMBAHASAN}

\section{Keadaan Umum Kawasan}

Upaya pengelolaan Hutan Gunung Meja sebagai kawasan lindung dimulai pada bulan Agustus 1953, yaitu saat kunjungan Tim Kehutanan Pemerintah Belanda, yang terdiri atas : Ir. J.F.V.Zieck (Kepala Seksi Inventarisasi Hutan), Ir. J. Fokkinga (Ketua Komisi Pertanian) dan H. Schrijn (Kepala Pemangkuhan Hutan) ke Gunung Meja. Pada saat itu, telah disepakati areal hutan primer seluas 100 ha dan hutan sekunder seluas 360 ha termasuk jurang dan tebing-tebing karang yang ada untuk diusulkan sebagai hutan lindung Hidroorologi.

Hutan Gunung Meja sendiri mengalami beberapa kali proses terkait perubahan status kawasan sebagaimana dapat dilihat pada Tabel 1 .

Sejak awal pemerintah Belanda menetapkan Hutan Gunung Meja sebagai kawasan lindung dengan fungsi utama pengatur tata air (Hutan Lindung Hidrorologis). Perkembangan selanjutnya dengan mempertimbangkan letak dan jarak dengan pusat Kota Manokwari, sehingga dikembangkan aneka fungsi kawasan bagi masyarakat maupun lingkungan. Rencana fungsi pengembangan yang diprakarsai pemerintah Belanda, antara lain :

1 Fungsi pendidikan dan pelatihan di bidang kehutanan

2 Fungsi penelitian

3 Taman Hutan/Botani Garden

4 Tempat rekreasi untuk masyarakat kota Manokwari.

Sejumlah upaya pengelolaan dilakukan oleh pemerintah Belanda dalam rangka mendukung rencana pengembangan fungsi kawasan hutan Gunung Meja adalah, sebagai berikut :

1 Kegiatan inventarisasi hutan primer dan menjelang awal tahun 1954 
mencapai $100 \mathrm{Ha}$ dan dilanjutkan pada tahun 1956 dan 1957 hingga mencapai $360 \mathrm{Ha}$.

2 Sejalan dengan kegiatan inventarisasi hutan, telah dilakukan survei tanah dan analisis vegetasi pada kawasan hutan Gunung Meja untuk jenis pohon yang berdiameter lebih dari $35 \mathrm{~cm}$ dengan intensitas sampling adalah $10 \%$ oleh pengenal jenis lokal Bapak Jance Ainusi dan seorang ahli Botani Belanda Ir. Faber.

3 Pada tahun 1956 dilakukan pemetaan areal hutan Gunung Meja seluas 360 Ha oleh Kantor Agraria Manokwari.

4 Sesuai rencana pengembangan fungsi kawasan yang dibuat oleh pemerintah, maka untuk mencapai semua tujuan pengembangan fungsi kawasan dibutuhkan areal seluas 700 hektar.

Realisasi pengelolaan kawasan tidak dapat dilaksanakan sesuai rencana yang ditetapkan, karena situasi politik yang mengharuskan Pemerintah Belanda untuk meninggalkan Nederland Neuw Guinea (Tanah Papua) sekitar tahun 1960-an. Pada tahun 1963, kewenangan pengelolaan kawasan Hutan Gunung Meja diserahkan dari pemerintah Belanda kepada Pemerintah Provinsi Papua Barat dan selanjutnya, berdasarkan surat keputusan Gubernur Irian Barat tahun 1963, kawasan dipertahankan sebagai kawasan lindung dengan fungsi utama adalah Hutan Lindung Hidroologis. Upaya pengelolaan yang dilakukan oleh Dinas Kehutanan pada saat itu terbatas pada pengamanan hutan dan penyuluhan kepada masyarakat sekitar hutan. Tidak tersedianya data sehingga informasi pengelolaan hutan Gunung Meja dalam periode 1963 sampai 1980-an tidak dapat dideskripsikan, namun demikian pengelolaan tetap dilaksanakan oleh pemerintah yang bertumbuh pada fungsi kawasan sebagai hutan lindung.

Tabel 1. Sejarah Penetapan Taman Wisata Alam Gunung Meja

\begin{tabular}{|c|c|c|}
\hline aht & Uraian & Le \\
\hline 1950 & $\begin{array}{l}\text { Larangan melakukan penebanga } \\
\text { hutan Gunung Meja }\end{array}$ & Instruksi Kepala Pemangku Hutan \\
\hline 1953 & $\begin{array}{l}\text { Kunjungan Kepala Seksi } \\
\text { Inventarisasi Hutan, Ketua Komisi } \\
\text { Pertanian dan Kepala Pemangku } \\
\text { Hutan Ke Gunung Meja }\end{array}$ & 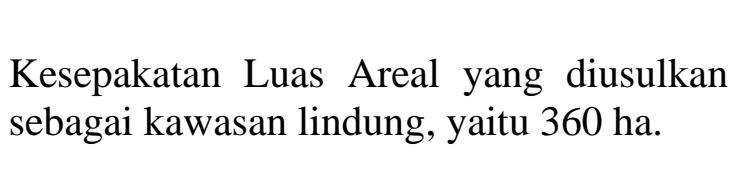 \\
\hline 1954 & $\begin{array}{l}\text { Pendaftaran Hutan Gunung Meja } \\
\text { pada Ordonansi Perlindungan Tanah }\end{array}$ & Lembaran Negara Nomor 7 \\
\hline 1957 & $\begin{array}{l}\text { Penetapan Hutan Gunung Meja } \\
\text { sebagai Hutan Lindung dengan } \\
\text { fungsi Hidroorologis seluas } 358,50 \\
\text { Ha }\end{array}$ & $\begin{array}{l}\text { Surat Keputusan Gubernur Nederland } \\
\text { Nieuw Guinea Nomor } 158 \text { Tanggal } 25 \\
\text { Mei } 1957\end{array}$ \\
\hline 1963 & $\begin{array}{l}\text { Gunung Meja sebagai Hutan } \\
\text { ing Hidrologis telah berlaku } \\
\text { in luasan } 468,50 \mathrm{Ha}\end{array}$ & $\begin{array}{l}\text { Surat Keputusan Gubernur Irian } \\
\text { Nomor } 44 / G I B / 1963 \text { tanggal } \\
\text { September } 1963\end{array}$ \\
\hline 1980 & $\begin{array}{l}\text { Hutan Lindung Gunung Meja } \\
\text { dirubah menjadi Hutan Wisata } \\
\text { Alam dengan luas } 500 \mathrm{Ha}\end{array}$ & $\begin{array}{l}\text { Keputusan Menteri Pertanian No. } \\
\text { 19/Kpts/Um.I/1980 tanggal } 12 \text { Januari } \\
1980\end{array}$ \\
\hline 2012 & $\begin{array}{l}\text { Taman Wisata Alam dengan luas } \\
462,16 \mathrm{Ha}\end{array}$ & $\begin{array}{l}\text { Keputusan Menteri Kehutanan No.SK.91/ } \\
\text { Menhut-II/2012 tanggal 3/02/2012 }\end{array}$ \\
\hline
\end{tabular}


Di tahun 1980-an hutan lindung Gunung Meja dirubah fungsinya menjadi Taman Wisata Alam melalui Surat Keputusan Menteri Pertanian RI No : 19/Kpts/Um/I/1980. Sejak saat itu, kewenangan pengelolaan kawasan yang tadinya pada Dinas Kehutanan dialihkan kepada Balai Konservasi Sumber Daya Alam Papua II melalui Seksi Konservasi Wilayah I Manokwari. Perubahan fungsi ini didasarkan pada beberapa pertimbangan dan rekomendasi yang diberikan oleh pemerintah daerah, yaitu kawasan hutan ini letaknya strategis dekat pusat kota Manokwari dan mudah diakses, memiliki nilai keindahan alam yang artistik dan situs sejarah bangsa. Selain hutan ini diharapkan akan menjadi salah satu sumber pendapatan asli daerah (PAD) dan juga penambah devisa negara pada sektor kepariwisataan selain sektor lainnya.

Upaya-upaya yang dilakukan dengan adanya perubahan fungsi kawasan menjadi Taman Wisata Alam Gunung Meja adalah, sebagai berikut :

1. Tahun 1982 dilakukan penataan batas kawasan oleh Sub Balai Planologi Kehutanan VI Maluku Papua. Luas kawasan secara definitif 460,25 dengan panjang pal batas kawasan adalah $10,97 \mathrm{Km}$.

2. Tahun 1990 dilakukan rekonstruksi tata batas Kawasan oleh Sub. Balai Inventarisasi dan Perpetaan Hutan Manokwari dengan luasan dan panjang pal batas yang sama pula.

3. Kegiatan pembangunan home stay proyek kawasan lindung

4. Kegiatan agroforestry dengan masyarakat di kampung Ayambori

5. Kegiatan pemeliharaan pal batas secara partisipatif dengan masyarakat

Kegiatan-kegiatan yang dilakukan sejak tahun 1980-an hingga saat ini belum ada yang terkait langsung dengan pengelolaan kawasan sesuai fungsinya sebagai taman wisata alam. Kegiatan yang dilakukan hanya berupa upaya pengamanan hutan, penyuluhan dan penyadaran kepada masyarakat sekitar hutan. Kecuali, pembangunan Tugu Jepang oleh Dinas Pariwisata Kabupaten Manokwari sebagai obyek wisata sejarah atau situs sejarah perang dunia II dalam kawasan sebagai upaya memperkaya objek wisata sejarah.

Pada tahun 2012 kawasan Taman Wisata Gunung Meja SK.91/Menhut11/2O12 kawasan ini tetap dipertahankan sesuai fungsinya, namun mengalami perubahan luas kawasan yaitu bertambah menjadi 462,16 ha. Pengelolaan tetap saja dilakukan sebagaimana tahun-tahun sebelumnya berdasarkan rencana pengelolaan yang direncanakan dengan tujuan mempertahankan eksistensi kawasan dengan mengoptimalkan fungsinya sebagai taman wisata alam.

\section{Letak, Luas dan Batas Wilayah}

Kawasan Taman Wisata Gunung Meja secara geografis terletak pada $134^{\circ} 03$ '17' - 134 04'05" Bujur Timur dan 0'51'29" - 0'52'59" Lintang Selatan. Luas kawasan hutan ini 462,16 $\mathrm{Ha}$ dan terletak di tengah di kota Manokwari sehingga cukup strategis terhadap berbagai aktivitas kehidupan.

Berdasarkan pembagian wilayah administrasi pemerintahan, Taman Wisata Alam Gunung Meja berada pada 2 wilayah pemerintahan distrik (kecamatan) yaitu distrik Manokwari Barat dan distrik Manokwari Timur. Pada kedua distrik ini mencakup 5 wilayah kelurahan masing-masing kelurahan Amban, kelurahan Padarni, kelurahan Manokwari Timur, kelurahan Manokwari Barat dan kelurahan Pasir Putih. 
Batas-batas wilayah Taman Wisata Gunung Meja sebagai berikut. Sebelah Utara: Pantai Laut Pasifik Sebelah Selatan: Kota Manokwari Sebelah tenggara: Kelurahan pasir putih Sebelah Barat Laut: Kelurahan Amban

\section{Iklim}

Berdasarkan data iklim yang diperoleh dari Badan Meteorologi dan Geofisika Wilayah V Stasiun Meteorologi Kelas III Manokwari selama 20 tahun terakhir (1994 - 2013), diketahui bahwa kawasan TWA Gunung Meja seperti halnya wilayah tropis lainnya memiliki kondisi iklim yang baik guna menunjang pertumbuhan dan perkembangan sumber daya alam. Jumlah curah hujan tertinggi di kawasan Taman Wisata Alam Gunung Meja pada tahun 2012 yaitu $2978 \mathrm{~mm}$ dan terendah pada tahun 2003 yaitu 1572 mm. Rataan hari hujan berkisar antara 11,70 sampai 21,05 hari dengan intensitas hujan tertinggi pada tahun 1994 yaitu 17,97 mm/hari hujan dan terendah pada tahun 2008 dan 2010 masing-masing 7,2 mm/hari.

Temperatur atau suhu udara di kawasan Taman Wisata Alam Gunung Meja dan sekitarnya berkisar antara $27,0^{\circ} \mathrm{C}$ sampai $27,32^{\circ} \mathrm{C}$. Suhu udara tahunan tertinggi terjadi pada tahun 2002, 2003, 2004, 2007, 2008 dan 2010 yaitu $27,3^{\circ} \mathrm{C}$ dan terendah pada tahun 2001 yaitu $27,0^{\circ} \mathrm{C}$. Rataan kelembaban udara di kawaan hutan ini dan sekitarnya berkisar antara $81,17 \%$ sampai $84,25 \%$ dengan kelembaban udara tertinggi pada tahun 2001 sebesar $84,25 \%$ dan terendah pada tahun 2009 yaitu $81,17 \%$.

Berdasarkan data curah hujan bulanan tersebut, selanjutnya ditabulasikan berdasarkan kriteria bulan basah, bulan sedang dan bulan kering sebagaimana dapat dilihat pada Tabel 2 .

Tabel 2. Jumlah Bulan Kering, Bulan Lembab dan Bulan Basah di Kawasan Taman Wisata Gunung Meja dan Sekitarnya Selama 20 Tahun Terakhir (1994-2013)

\begin{tabular}{cccc}
\hline Tahun & $\begin{array}{c}\text { Bulan kering } \\
(<60 \mathrm{~mm})\end{array}$ & $\begin{array}{c}\text { Bulan lembab } \\
(60-100 \mathrm{~mm})\end{array}$ & $\begin{array}{c}\text { Bulan basah } \\
(>100 \mathrm{~mm})\end{array}$ \\
\hline 1994 & 1 & 2 & 9 \\
1995 & 2 & 2 & 8 \\
1996 & 1 & 2 & 9 \\
1997 & 2 & 2 & 8 \\
1998 & 1 & 2 & 9 \\
1999 & 1 & 2 & 9 \\
2000 & 2 & 2 & 8 \\
2001 & 1 & 2 & 9 \\
2002 & 3 & 2 & 7 \\
2003 & 3 & 3 & 6 \\
2004 & 3 & 2 & 7 \\
2005 & 0 & 2 & 10 \\
2006 & 1 & 1 & 10 \\
2007 & 0 & 0 & 12 \\
2008 & 1 & 5 & 6 \\
2009 & 2 & 2 & 8 \\
2010 & 2 & 3 & 7 \\
2011 & 3 & 4 & 5 \\
2012 & 3 & 3 & 6
\end{tabular}




\begin{tabular}{cccc}
2013 & 3 & 3 & 6 \\
\hline Jumlah & 35 & 46 & 159 \\
\hline Rataan & 1,75 & 2,3 & 7,95
\end{tabular}

Sumber : Badan Meteorologi dan Geofisika Manokwari (2014)

Penentuan bulan basah dan bulan kering menggunakan kriteria Schmidt dan Fergusson (1951) dalam Sinery (2013) sebagaimana terlihat pada tabel di atas. Asumsi dasar pengelompokkan ini yakni bahwa bulan kering adalah bulan dengan curah hujan $<60 \mathrm{~mm}$, bulan lembab adalah bulan dengan curah hujan 60-100 mm, dan bulan basah adalah bulan dengan curah hujan $>100$ mm. Perbandingan rata-rata bulan basah dengan bulan kering yang dinyatakan dalam \% (nilai Q). Nilai Q tersebut dapat dihitung dengan menggunakan persamaan sebagai berikut.

$$
\begin{aligned}
Q & =\frac{\text { Jumlah bulan kering }}{\text { Jumlah bulan basah }} \times 100 \% \\
& =\frac{35}{159} \times 100 \%=22,01 \%
\end{aligned}
$$

Gambaran tentang klasifikasi tipe iklim berdasarkan sistem klasifikasi Schmidt dan Fergusson dapat dilihat pada Tabel 3.

Tabel 3. Klasifikasi Tipe Iklim di TWA Gunung Meja Menurut Sistem Schmidt dan Fergusson

\begin{tabular}{cc}
\hline Tipe Iklim & Nilai Q $(\%)$ \\
\hline A & $0-<15,3$ \\
B & $\mathbf{1 5 , 3 - < 3 3 , 3}$ \\
C & $33,3-<60$ \\
D & $60-<100$ \\
E & $100-<167$ \\
F & $167-<300$ \\
G & $300-<700$ \\
H & $>700$ \\
\hline
\end{tabular}

Sesuai hasil analisis data curah hujan di atas, kawasan Taman Wisata Gunung Meja memiliki tipe iklim termasuk tipe iklim tropik basah dengan nilai $\mathrm{Q}=15,3-<33,3$.

\section{Topografi dan Kelerengan}

Kawasan yang berada pada ketinggian antara $16-210 \mathrm{~m} \mathrm{dpl}$ dengan topografi lapangan bervariasi dari datar hingga bergelombang ringan ke arah timur dan bergelombang berat dari timur ke arah barat dengan puncak tertinggi (puncak Bonay) \pm 210 meter dpl. Pada sisi bagian selatan dan utara terdapat beberapa tempat yang tebing karang terjal dan lereng yang curam. Pada puncak terdapat daerah yang relief yang kecil hampir datar menyerupai permukaan meja sehingga kawasan ini dinamakan Gunung Meja (Tafelberg). Fisiografi lahan dengan tebing karang terjal dan berteras pada sisi sebelah selatan ke barat laut kawasan merupakan wilayah penyebaran mata air.

Kondisi areal TWA Gunung Meja memilik kelas kelerengan datar $(0-8 \%)$ sampai sangat curam $(>40 \%)$. Kondisi kelas lereng secara rinci dapat dilihat pada Lampiran Peta Kelerengan TWA Gunung Meja. Menurut Peday (2009) kawasan Taman Wisata Alam Gunung Meja memiliki kondisi fisiografi yang cukup bervariasi. Fisiografi tersebut mencakup wilayah berkelerengan $0-8 \%$ (datar) seluas 188,70 ha $(41 \%)$, wilayah berkelerengan $8-15 \%$ (landai) seluas 41,42 ha (9\%), wilayah berkelerengan $15-25 \%$ (agak curam) seluas 179,50 ha $(39 \%)$, wilayah berkelerengan 25 - 
$40 \%$ (curam) seluas 32,22 ha $(7 \%)$ dan wilayah berkelerengan $>40 \%$ (sangat) seluas 4 ha $(18,41 \%)$. Agak kelerengan wilayah berkisar antara datar sampai sangat curam.

\section{Geologi dan Tanah}

Berdasarkan peta geologi wilayah Manokwari kerjasama Pusat Penelitian dan Pengembangan Geologi, Departemen Pertambangan Energi dan Bureau of Mineral Resources, Geology and Geophysics, Departmen of Primary Industrial and Energy Australia diketahui bahwa kawasan taman Wisata alam Gunung Meja dilalui Formasi Manokwari (Qpm) yang merupakan formasi batuan yang terdiri atas batu gamping terumbu, kalsirudit, kalkarenit, dan batupasir, konglomerat breksi nakabahan, dan gampingan. Menurut Leppe dan Tokede (2004); Liborang (2004); BBKSDA (2008), kawasan ini terdiri atas jenis batuan sedimen neogen dengan variasi tanah pasir dan tanah liat berpasir. Tanah pasir tanpa batu berwarna coklat kemerah-merahan, tanah liat berpasir dengan batu berwarna coklat kemerah- merahan, tanah liat berpasir di atas batuan karang berwarna coklat kemerah-merahan, tanah liat kemerah-merahan tanpa batu dan tanah kemerah-merahan dengan batu serta tanah liat kemerah-merahan di atas batu karang.

Dari jenis-jenis tersebut batu gamping merupakan sistem geologi yang menjadi pertimbangan lain nantinya dalam pengelolaaan hutan ini sesuai Surat Keputusan Menteri Energi dan Sumber Daya Mineral No.1456/20/MEM/2000 tentang Pemanfaatan dan Perlindungan Kawasan Karst. Hal tersebut didasarkan pentingnya kawasan karst sebagai ekosistem spesifik untuk eksistensi flora dan fauna spesifik.
Terkait dengan fungsi karbon, maka pelestarian ekosistem Karst merupakan pelestarian jasa lingkungan berupa penyerapan karbondisoksida di udara secara alami. Menurut Cahyadi (2000) dalam Sinery (Sinery, 2013) bahwa proses penyerapan karbondioksida diawali dengan larutnya karbondioksida $\left(\mathrm{CO}_{2}\right)$ di dalam air dan membentuk $\mathrm{H}_{2} \mathrm{CO}_{3}$. Sifat larutan $\mathrm{H}_{2} \mathrm{CO}_{3}$ yang tidak stabil akan mudah terurai menjadi $\mathrm{HCO}_{3}{ }^{2-}$ dan $\mathrm{H}^{+}$dan $\mathrm{HCI} \mathrm{O}_{3}{ }^{-}$. Proses ini berlangsung dengan kesetimbangan reaksi kimia tertentu dan setiap pelarutan $1000 \mathrm{~kg}$ batu gamping $\left(\mathrm{CaCO}_{3}\right)$ pasti diikuti oleh penyerapan karbondioksida $\left(\mathrm{CO}_{2}\right)$ sebanyak $120 \mathrm{~kg}$. Menurut Ko (2006) dalam Sinery (2013) ekosistem Karst sangat penting bagi kehidupan karena ekosistem ini berfungsi sebagai pemasok air bagi kebutuhan komponen lingkungan lainnya. Hal tersebut dipertegas PBB (UN) yang mengemukakan bahwa $25 \%$ persediaan air bagi kebutuhan penduduk dewasa ini dipasok dari sumber air karst (Sinery, 2013).

Gambaran secara rinci menganai sifat fisik tanah di bawah lima jenis tegakan hutan dan tanah kosong pada kedalaman $20 \mathrm{~cm}$ di Kawasan Taman Wisata Alam Gunung Meja dapat dilihat pada Tabel 4.

Tanah di hutan TWA Gunung Meja berdasarkan karakteristik tanahnya digolongkan kedalam empat jenis tanah dan umumnya memiliki lapisan atas (top soil) yang sangat tipis $(<30 \mathrm{~cm})$. Tanah tersebut adalah tanah liat, tanah berkapur, tanah berbatu dan tanah berkarang. 
Tabel 4. Sifat fisik Tanah pada di Kawasan Taman Wisata Gunung Meja

\begin{tabular}{|c|c|c|c|c|}
\hline \multirow{2}{*}{$\begin{array}{l}\text { Jenis tegakan/ } \\
\text { tutupan lahan }\end{array}$} & \multicolumn{3}{|c|}{ Fraksi } & \multirow{2}{*}{$\begin{array}{c}\text { Klasifikasi } \\
\text { tekstur tanah }\end{array}$} \\
\hline & Pasir (\%) & Debu $(\%)$ & Liat $(\%)$ & \\
\hline Calophyllum sp. & 5.93 & 43.93 & 50.14 & Liat berdebu \\
\hline Koordersiodendron sp. & 0.83 & 51.64 & 47.53 & Liat berdebu \\
\hline Palaquium sp. & 34.42 & 52.23 & 13.34 & Lempung berdebu \\
\hline Tectona grandis & 5.16 & 61.18 & 33.66 & Lempung liat berdebu \\
\hline Hutan alam & 4.98 & 83.47 & 12.54 & Lempung berdebu \\
\hline Tanah kosong & 4.65 & 61.36 & 33.99 & Lempung liat berdebu \\
\hline
\end{tabular}

Sumber : Liborang (2004); Manusawai (2014)

Perbedaan jenis tanah tersebut terlihat juga oleh perbedaan vegetasi yang tumbuh diatasnya. Tekstur tanah pada kawasan hutan TWA Gunung Meja adalah lempung berliat, liat berdebu, lempung liat berdebu dan liat, dengan kandungan liat berkisar antara 27,58 $61,18 \%$, debu 35,04-52,97\% dan pasir $2,12-28,32 \%$. Tanah bersifat agak masam (pH berkisar 5,94-6,56) sampai netral (pH berkisar 6,71-6,98), Corganik tersedia berkisar sangat rendah sampai tinggi, $\mathrm{N}$-total tersedia berkisar sangat rendah sampai rendah, $\mathrm{P}_{2} \mathrm{O}_{5}$ tersedia berkisar sedang sampai tinggi, Kapasitas Tukar Kation (KTK) tersedia berkisar rendah sampai sedang, $\mathrm{Ca}$ tersedia rendah sampai sedang, $\mathrm{Mg}$ tersedia berkisar sedang sampai tinggi, $\mathrm{K}$ tersedia berkisar rendah sampai sedang, $\mathrm{Na}$ tersedia berkisar rendah sampai sedang dan kejenuhan basa (KB) tersedia berkisar rendah sampai sedang.

Berdasarkan kondisi sifat tanah tersebut, diketahui bahwa jenis tanah di kawasan ini tergolong jenis tanah marginal dengan tingkat kesuburan sangat rendah sampai sedang.

\section{Aksesibilitas}

Perjalanan menuju lokasi

TWA Gunung Meja tidak sulit karena mempunyai aksesibilitas yang tinggi. Kebijakan pembangunan transportasi diarahkan untuk meningkatkan aksesibilitas antara ibu kota Kabupaten dengan daerah pedalaman sangat mendukung dalam mengakses di TWA Gunung Meja.

Aksesibilitas menuju kawasan TWA Gunung Meja dapat ditempuh melalui jalan darat, air dan udara. Saat ini transportasi jalan darat menuju kawasan hutan ini cukup potensial baik antar distrik maupun maupun antar kabupaten. Peningkatan fasilitas jalan terus dilakukan oleh pemerintah dalam rangka menunjang penyelanggaraan pembangunan. Untuk transportasi udara dilakukan dengan peningkatkan prasarana bandara Rendani dengan telah beroperasinya maskapai penerbangan berbadan besar/jet seperti Expres Air, Lion Air (Boing 737-400) dan Garuda. Tidak terbatas saja pada peningatan fasilitas pelabuhan udara, namun pembangunan perhubungan laut juga diprioritaskan untuk meningkatkan fasilitas pelabuhan laut Manokwari. Pelabuhan Manokwari disinggahi oleh Kapal Pelni, yaitu KM. Labobar, KM. Sinabung, dan KM. Ngapulu. Banyaknya penumpang yang menggunakan transportasi dapat dijadikan acuan untuk memperkirakan jumlah wisatawan yang datang.

\section{Nilai Estetika}

\begin{tabular}{lrrr}
\multicolumn{3}{c}{ Nilai estetika kawasan TWA } \\
Gunung Meja terbentuk atas \\
perpaduan antara posisi kawasan \\
terhadap & kota Manokwari, \\
karakteristik & fisiografi lahan,
\end{tabular}


keanekaragaman flora dan fauna serta nilai historis. Menurut BBKSDA Papua Barat (2008); Manusawai (2014) posisi kawasan terhadap kota Manokwari, karakteristik fisiografi lahan, keanekaragaman flora dan fauna serta nilai historis merupakan nilai keunikan yang penuh kerahasiaan dan keajaiban ciptaan Tuhan. Kota Manokwari memiliki keunggulan alami karena secara geografis mempunyai panorama dengan nilai keindahan alam yang sangat unik. Terletak sepanjang pantai Teluk Doreri dan dihiasi dua pulau kecil "Pulau Lemon dan Mansinam" di depannya. Sedangkan pada belakang kota di pagari hijauan pepohonan, tebing yang terjal dan curam membentuk suatu gugusan bukit yang indah (Gunung Meja). Apabila kita memandang lebih jauh ke arah Selatan sampai Barat Daya membentang pegunungan Afrak yang menjulang. Bentangan alam ini, baik berupa pulau di depan Teluk Doreri, jajaran pegunungan Afrak dan Gunung Meja merupakan kawasan penyangga (Buffer zone) Kota Manokwari terhadap kejadian dan gejala alam yang mungkin tejadi.

Menurut BBKSDA Papua Barat (2008) letak kawasan Gunung Meja yang berbatasan dengan wilayah kota Manokwari merupakan kepariwisataan yang cukup potensial. Keunggulan dan keunikan ini semakin diperkuat oleh karakteristik fisiografi lahan Gunung Meja yang melatarbelakangi kota. Merupakan jajaran pegunungan elevasi tertinggi 110 meter di atas permukaan laut yang di beberapa sisinya ditutupi tebing yang terjal dan lereng yang curam menampakan panorama alam yang indah. Panorama yang sama jika kita berada pada salah satu sisi tertinggi di kawasan sejauh mata memandang tampak panorama laut dengan pantai pasir putih dan pantai karang serta laut yang dikelilingi pengunungan. Nilai estetika tersebut akan lebih mengagumkan lagi bila dinilai dari tipe hutan, keanekaragaman serta keendemikan flora-fauna yang merupakan keterwakilan (holotype) type hutan tropis dataran rendah yang hampir dijumpai di sepanjang pantai utara pulau New Guinea. Keunikankeunikan tersebut menjadi daya tarik bagi penjelajah alam dan pemerhati lingkungan. Daya tarik ini akan semakin kuat apabila dipadukan dengan nilai sejarah yang terkandung dalam kawasan, karena Gunung Meja dapat menjadi saksi sejarah dari zaman Belanda, Jepang dan zaman Sekutu dalam masa penjajahan di tanah ini.

Potensi estetika tersebut yang menjadi dasar utama menetapkan Gunung Meja sebagai salah satu kawasan pelestarian alam di Manokwari dengan fungsi utama Wisata Alam. Keunggulan dan keunikan potensi alam inilah yang perlu ditumbuhkembangkan untuk memperkaya nilai kepariwisataan sebagai salah satu upaya meningkatkan pendapatan daerah serta penunjang kebutuhan hidup masyarakat.

\section{a. Potensi Taman Wisata Alam Gunung Meja}

\section{Tutupan Lahan}

Berdasarkan hasil tumpang susun (overlay) data citra satelit dan peta kawasan Taman Wisata Alam Gunung Meja (SK Menhut No.91/MenhutII/2012) dan beberapa peta tematik seperti peta jaringan jalan Papua Barat, data sebaran kampung Papua Barat dan 
data tata batas TWA Gunung Meja tahun 2011 serta beberapa data lainnya diketahui, bahwa ada beberapa tipe tutupan lahan di TWA Gunung Meja dan didominasi oleh tipe tutupan lahan hutan primer yang merupakan salah satu potensi pengembangan kawasan ini.

Hasil análisis dan pengamatan menunjukkan bahwa hutan primer merupakan tipe tutupan lahan paling luas di wilayah TWA Gunung Meja yaitu seluas 357,98 ha atau $77,46 \%$ dari luas TWA ini dan tersebar secara merata di kawasan hutan ini. Struktur dan komposisi jenis yang cukup bervariasi menjadikan hutan ini kaya akan jenis-jenis vegetasi hutan seperti jenis-jenis tumbuhan berkayu, liana dan epifit. Demikian halnya dengan asosiasi jenis yang tinggi baik flora maupun fauna. Struktur vegetasi jelas terlihat dengan stratifikiasi tajuk yang menunjukkan adanya formasi jenis-jenis tertentu di hutan ini. Kondisi tersebut menjadikan hutan ini potensial sebagai obyek wisata yang perlu dipertimbangkan terkait pengembangan wisata dan pendidikan serta penelitian.

Hutan tanaman merupakan tipe tutupan lahan yang lebih luas setelah hutan primer dengan luas areal 54,27 ha atau $11,74 \%$ dari luas kawasan TWA. Hutan ini terbentuk sebagai upaya peningkatan nilai kawasan sebagai laboratorium alam melalui penyediaan berbagai vegetasi bernilai ekonomi. Hutan ini berada di bagian utara di sepanjang jalan koridor yang membentang dari arah utara menuju selatan, termasuk pada bagian barat kawasan TWA ini.

Jenis-jenis tanaman yang ditanam pada kawasan ini terdiri atas Tectona grandis, Pometia spp., Koordersiodendron pinnatum,

Palaquium ambiinensis dan

vegetasi yang merata pada bebera jenis tegakan menjadikan pemandangan tersendiri bagi pengunjung yang memasuki kawasan ini sebagaimana dideskripsikan secara rinci selanjutnya.

Areal bekas kebun merupakan tipe tutupan lahan terluas selanjutnya setelah hutan primer dan hutan tanaman. Berdasarkan hasil analisis diketahui bahwa luas areal bekas kebun di kawasan TWA Gunung Meja adalah 25,92 ha atau 5,61\% dari luas kawasan hutan konservasi ini. Areal kebun tersebut tersebar pada bagian selatan dan timur kawasan Taman Wisata Alam Gunung Meja.

Areal-areal tersebut merupakan areal bekas kebun yang diusahakan oleh masyarakat sekitar kawasan yang pada beberapa waktu mendatang akan diusakan kembali. Diharapkan arealareal tersebut dapat dipertimbangkan secara baik dalam rencana pengelolaan agar dapat ditingkatkan kualitas dan kuantitasnya dimasa mendatang.

Tipe tutupan lahan selanjutnya yang diidentifikasi di TWA Gunung Meja adalah areal kebun. Berdasarkan hasil análisis, diketahui bahwa luas areal kebun di kawasan Taman Wisata Alam Gunung Meja 15,73 ha atau 3,40\% dari luas TWA Gunung Meja. Areal tersebut tersebar pada bagian barat dan selatan dari kawasan konservasi ini.

Kebun-kebun tersebut diusahakan oleh masyarakat sekitar kawasan dan merupakan suatu potensi terkait eksistensi kawasan sehingga perlu dilakukan pengelolaan secara baik dimasa mendatang sehingga terwujud keharmonisan pengelolaan bersama masyarakat.

Tutupan lahan lainnya adalah areal tanah terbuka dan fasilitas penunjang pengelolaan TWA seperti jalan, jaringan listrik dan pemancar telekomunikasi (tower). Hasil análisis 
menunjukkan, bahwa luas areal tanah terbuka di TWA Gunung Meja 3,41 ha atau $0,7 \%$ dari luas kawasan ini. Areal tanah terbuka terdapat di bagian selatan kawasan TWA dan merupakan dampak kegiatan penggalian material batuan dan tanah. Areal tersebut nantinya perlu dilakukan pengelolaan secara baik sehingga dapat menunjang fungsi kawasan TWA sebagai areal konservasi. Jaringan listrik juga merupakan tipe tutupan lahan lainnya yang diidentifikasi dengan luas areal 2,42 ha atau $0,5 \%$ dari luas TWA Gunung Meja. Fasilitas ini terdapat di bagian timur kawasan TWA mengikuti arah jalan raya menuju ke wilayah Litbang Kehutanan dan Kampung Ayambori. Tutupan lahan selanjutnya berupa jalan dengan luas areal 2,370 ha atau 0,5\% dari luas kawasan taman wisata ini.

Jalan di TWA Gunung Meja merupakan tipe tutupan lahan yang membentang dari arah utara (Kampung Ambon) menuju arah selatan (Perumahan Dosen Amban) dan menuju barat TWA (Kampung Ayambori dan Litbang Kehutanan). Jalan koridor tersebut merupakan peninggalan masa Perang Dunia II, namun masih dalam kondisi baik dan dimanfaatkan untuk akses menuju kawasan ini. Kondisi jalan umumnya baik, namun di beberapa lokasi ada kerusakan sehingga perlu diperbaiki. Tutupan lahan terkahir yang diidentifiasi sesuai luasannya adalah pemancar telekomunikasi (tower). Luas areal ini tower di kawasan TWA Gunung Meja adalah 0,05 ha atau $0,01 \%$ dari luas TWA Gunung Meja. Fasilitas tower tersebut berada di bagian selatan kawasan TWA di pinggir jalan meunju Kampung Ayambori.

Potensi pendukung pengelolaan TWA Gunung Meja lainnya adalah tower (menara pemancar) dengan luas areal 0.054 ha. Berbeda dengan tipe tutupan lahan lainnya, areal tower sangat kecil karena terbatas pada luas bangunan tower yang terdapat di sekitar wilayah kampung Ayambori. Keberadaan fasilitas ini sangat penting bagi masyarakat sekitar kawasan termasuk pengunjung sehingga dalam pengelolaannya perlu perhatiaan yang baik.

\section{Flora dan Fauna}

Taman Wisata Alam Gunung Meja merupakan salah satu kawasan hutan yang memiliki potensi flora dan fauna serta ekosistem yang cukup bervariasi. Berdasarkan hasil-hasil penelitian sebelumnya diketahui bahwa potensi flora yang terdapat di kawasan ini terdiri atas tumbuhan semak, perdu dan herba, liana daPn rotan, angrek (epifit), paku-pakuan, bambu dan palem serta tumbuhan berkayu baik pada hutan alam maupun hutan tanaman. Menurut BBKSDA Papua Barat (2008) kawasan TWA Gunung Meja terdapat 2 (dua) tegakan hutan, yaitu tegakan hutan alam (primer) dan tegakan hutan tanaman. Tegakan hutan alam terdapat pada bagian Utara dan bagian Timur kawasan TWA Gunung Meja.

a. Hutan primer

Berdasarkan data hasil penelitian diketahui bahwa kawasan Taman Wisata Gunung Meja memiliki potensi vegetasi hutan yang cukup tinggi. Di kawasan hutan ini diidentifikasi 223 jenis vegetasi hutan yang mencakup 159 jenis vegetasi tingkat pohon, 149 jenis vegetasi tingkat tiang, 164 jenis vegetasi tingkat pancang dan 177 jenis vegetasi tingkat semai. Jenis-jenis vegetasi hutan tersebut diantaranya Pometia coreacea, Pimelodendron amboinicum, Pometia pinnata, Pterygota horsfieldia, Haplolobus lanceolata, Spathiostemon javensis, Koordersiodendron pinnatum., Euodia elleriana. dan berbagai jenis lainnya 
sebagaimana tercantum pada Gambar 1, Gambar 2, Gambar 3 dan Gambar 4.

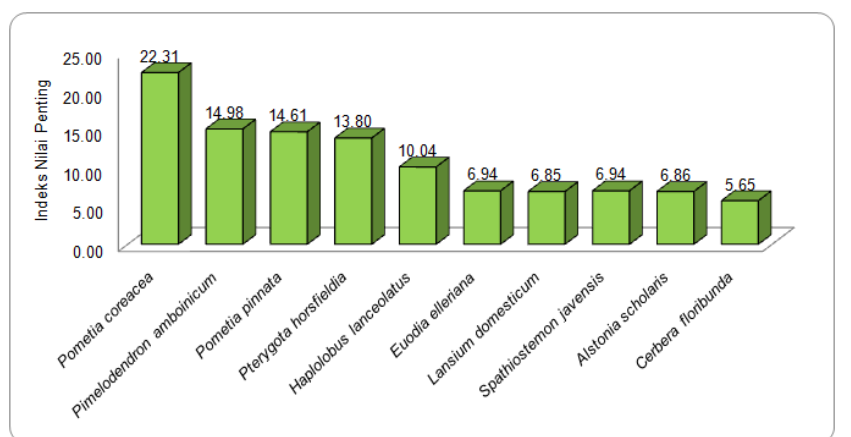

Gambar 1. Indeks Nilai Penting 10 Jenis Vegetasi Tingkat Pohon di Taman Wisata Alam Gunung Meja

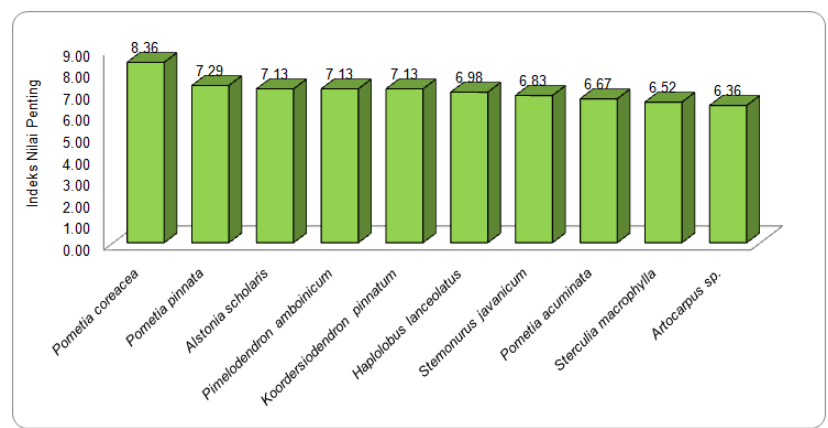

Gambar 2. Indeks Nilai Penting 10 Jenis Vegetasi Tingkat Tiang di Taman Wisata Alam Gunung Meja

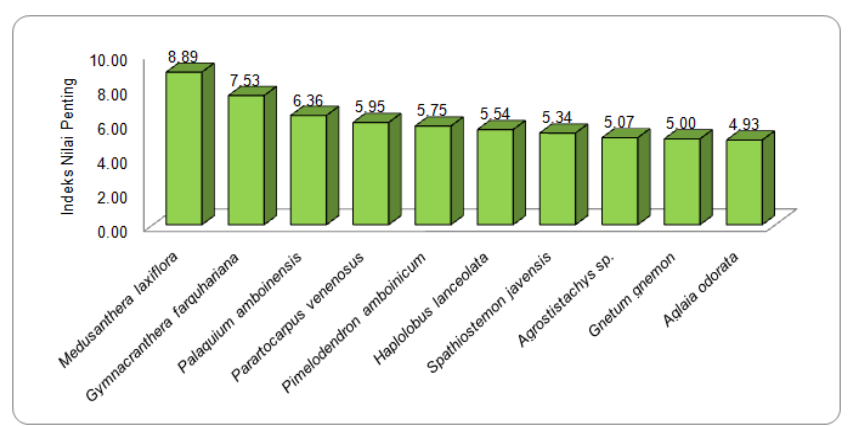

Gambar 3. Indeks Nilai Penting 10 Jenis Vegetasi Tingkat Pancang di Taman Wisata Alam Gunung Meja

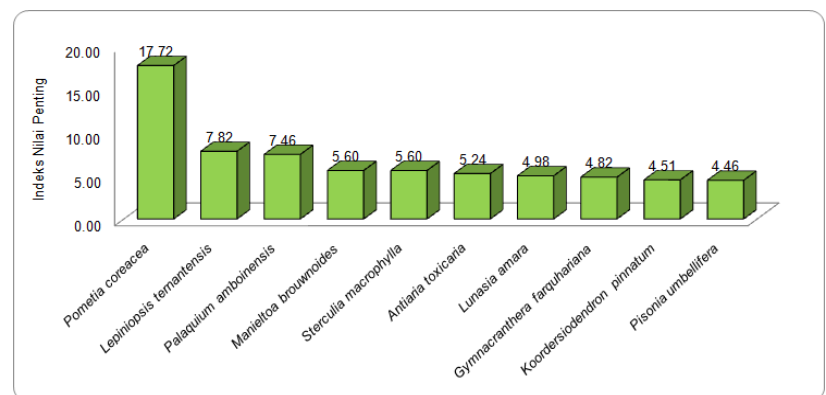

Gambar 4. Indeks Nilai Penting 10 Jenis Vegetasi Tingkat Semai di Taman Wisata Alam Gunung Meja 
Berdasarkan hasil analisis sebagaimana terlihat pada gambar diatas menunjukkan bahwa dari jenis-jenis vegetasi hutan yang diidentifikasi pada tingkat pohon Pometia coreacea merupakan jenis yang dominan dengan INP selanjutnya diikuti Pimelodendron amboinicum, Pometia pinnata, Pterygota horsfieldia dan jenis-jenis lainnya. Selanjutnya jenis-jenis dengan INP terendah yaitu Tetrameles nudiflora, Prunus sp., Praenea limpato, Spondias cytherea, Pouteria obovata, Litsea timoriana, Garcinia picrorrhiza, Fluggea racemosa, Archidendron parviflorum, Artocarpus vriesianus, Campnosperma brevipetiolata, Baccaurea papuana dan Calophyllum inophyllum.

Pada tingkat tiang seperti halnya pada tingkat pohon, didominasi oleh Pometia coreacea dengan INP tertinggi selanjutnya diikuti Pometia coreacea, Alstonia scholaris, Pimelodendron amboinicum, Koordersiodendron pinnatum dan berbagai jenis lainnya. Kondisi tersebut menggambarkan bahwa Pometia coreacea merupakan jenis yang memiliki kemampuan adaptasi yang sangat baik terhadap kondisi tempat tumbuh (habitat) sebagaimana tergambar dari kehadiran individu maupun penyebaran individu didalam petak pengamatan. Hasil pengamatan menunjukkan bahwa selain memiliki jumlah individu yang banyak, penyebaran individu jenis ini hampir dijumpai pada semua petak pengamatan yang menggambarkan adanya distribusi individu cukup merata pada hutan ini. Selanjutnya diidentifikasi 27 jenis vegetasi lainnya dengan INP terendah seperti Pisonia cauliflora, Paraltropis glabra, Pangium edule dan jenis lainnya.

Pada tingkat pancang tidak seperti halnya pada tingkat pohon dan tiang yang didominasi oleh Pometia coreacea. Pada tingkat ini didominasi oleh Medusanthera laxiflora dengan INP tertinggi selanjutnya diikuti Gymnacranthera farquhariana, Palaquium amboinensis, Parartocarpus venenosus dan berbagai jenis lainnya. Kondisi tersebut menggambarkan bahwa Medusanthera laxiflora merupakan jenis yang memiliki kemampuan adaptasi yang sangat baik terhadap kondisi tempat tumbuh (habitat) pada tingkat ini, namun tidak berkembang dengan baik khususnya pada tingkat tiang dan pohon. Selanjutnya diidentifikasi 27 jenis vegetasi lainnya dengan INP terendah seperti Pisonia cauliflora, Paraltropis glabra, Pangium edule dan jenis lainnya.

Pada tingkat semai seperti halnya pada tingkat tiang dan pohon, didominasi oleh Pometia coreacea dengan INP tertinggi selanjutnya diikuti Lepiniopsis ternantensis, Palaquium amboinensis dan berbagai jenis lainnya. Kondisi tersebut menggambarkan bahwa Pometia coreacea merupakan jenis yang memiliki kemampuan adaptasi yang sangat baik terhadap kondisi tempat tumbuh (habitat) sebagaimana tergambar dari kehadiran individu maupun penyebaran individu didalam petak pengamatan. Hasil

pengamatan menunjukkan bahwa selain memiliki jumlah individu yang banyak, penyebaran individu jenis ini hampir dijumpai pada semua petak pengamatan yang menggambarkan adanya distribusi individu cukup merata pada hutan ini. Menurut Wahyudi (2004) Pometia spp merupakan jenis dapat tumbuh pada tempat yang kadang-kadang tergenang air, pada tanah berpasir, berlempung, berkarang dan batu cadas. Habitat tempat tumbuh jenis ini dimulai dari kondisi kelerengan datar, bergelombang ringan sampai curam dengan ketinggian wilayah sampai $120 \mathrm{~m}$ dpl. 
Secara umum vegetasi hutan khususnya hutan alam cukup potensial pada kawasan TWA Gunung Meja. Data hasil penelitian menunjukkan bahwa potensi tegakan hutan alam di kawasan hutan ini mencakup potensi semai 32.300 individu /ha, pancang 3.904 individu/ha, tiang 867 individu /ha dan pohon 186 individu /ha dengan luas areal sampling 100 ha. Hal tersebut berbeda dengan Leppe dan Tokede (2004) yang menyatakan bahwa tegakan hutan alam pada bagian Utara dari kawasan hutan ini memiliki potensi semai 22.250 individu /ha, pancang 1.580 individu /ha, tiang 240 individu/ha dan pohon 124 individu/ha, sedangkan pada bagian Timur kawasan TWA Gunung Meja memiliki potensi semai 10.300 individu/ha, pancang 2.133 individu/ha, tiang 1.130 individu/ha dan pohon 131 individu/ha. Disebutkan lebih lanjut bahwa kawasan ini memiliki kekayaan flora yang cukup tinggi dan 40 jenis diantaranya merupakan jenis penghasil buah-buahan yang dapat dikonsumsi.

Menurut Smith (1962) dalam Sinery (2013), bahwa struktur suatu tegakan hutan sangat dipengaruhi oleh faktor-faktor yang berpengaruh terhadap pertumbuhan pohon penyusunnya, seperti faktor biotik dan genetik yang dimiliki setiap spesies pohon dan faktor lingkungannya. Struktur tegakan hutan selalu berubah menurut waktu, perubahan tersebut disebabkan oleh adanya kecepatan dari pertumbuhan dan kematian yang berupa kecepatan pertumbuhan diameter pohon dalam kelas diameter, adanya variasi ruang tumbuh yang diperlukan dalam pertumbuhan pohon, dan sebaran tegakan yang diperoleh.

Gambaran tingkat diversitas vegetasi hutan alam di kawasan ini yang mencakup vegetasi tingkat pohon, tiang, pancang dan semai sebagai gambaran kemantapan komunitas digambarkan melalui Indeks Keanekaragaman Jenis (H) sebagaimana dapat dilihat pada Gambar 5.

$$
\text { Hasil analisis tingkat }
$$

keanekaragaman jenis vegetasi hutan alam sebagaimana terlihat pada gambar diatas menunjukkan, bahwa indeks keanekaragaman jenis vegetasi hutan alam di TWA Gunung Meja tertinggi pada tingkat pohon $(4,38)$ dan terendah pada tingkat semai $(1,79)$. Kriteria indeks keanekaragaman atau derajat keanekeragaman jenis menurut Odum (1994) dalam Sinery dkk (2013) bahwa keanekaragaman jenis dinilai tinggi bila $\mathrm{H}>3$, sedang bila $1<\mathrm{H}<3$ dan rendah bila keanekaragaman jenis $\mathrm{H}<1$.

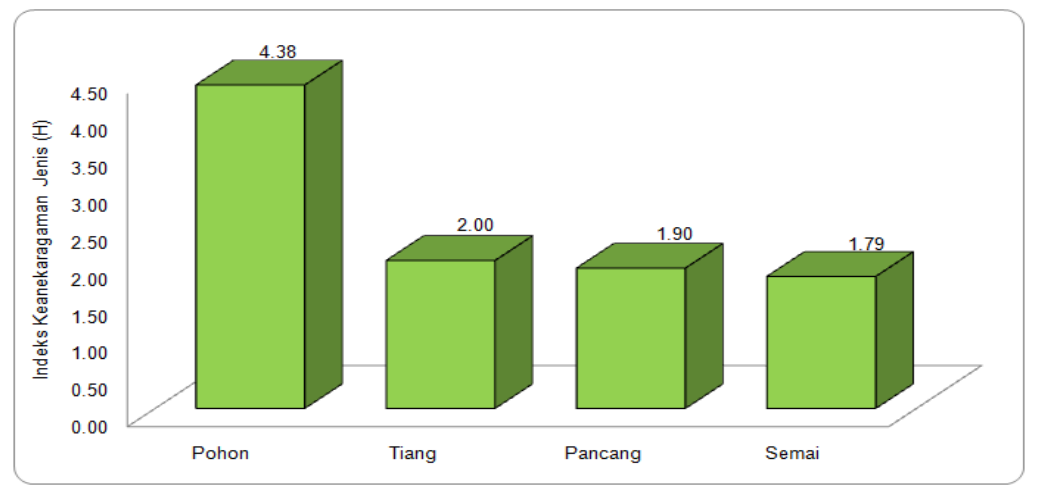

Gambar 5. Indeks Keanekaragaman Jenis Vegetasi Hutan Alam Pada Kawasan TWA Gunung Meja 
Dengan demikian indeks keanekaragaman jenis vegetasi hutan khususnya hutan alam di TWA Gunung Meja dikategorikan sedang sampai tinggi dengan rincian untuk tingkat pohon kriteria tinggi dan kriteria tingkat tiang, pancang dan semai adalah sedang. Kondisi tersebut dipengaruhi oleh kehadiran jenis dan penyebaran individu pada masing-masing jenis. Hubungannya adalah bahwa semakin tinggi jumlah jenis dan semakin tinggi kehadiran individu didalam jenis, maka indeks keanekaragaman jenis akan tinggi dan sebaliknya.

Suatu komunitas dikatakan mempunyai keanekaragaman jenis yang tinggi jika komunitas tersebut disusun oleh banyak spesies dengan kelimpahan yang sama atau hampir sama. Sebaliknya jika komunitas itu disusun oleh sangat sedikit spesies dan jika hanya sedikit saja jenis yang dominan maka keanekaragaman jenisnya adalah rendah. Hal tersebut akan tampak dengan semakin besarnya dominasi suatu jenis maka makin besar pula pengaruh pengoasaan jenis tersebut dan menunjukkan lebih terpusatkan pada satu atau beberapa jenis vegetasi pada suatu tingkat pertumbuhan. Hal tersebut terlihat dengan adanya vegetasi tingkat pohon yang lebih dominan dengan jumlah individu terbanyak dibanding vegetasi tingkat pertumbuhan lainnya yang didominasi oleh jenis-jenis vegetasi seperti Pometia coreacea, Pimelodendron amboinicum dan Pometia pinnata dan beberapa jenis lainnya.

Kawasan hutan Taman Wisata Alam Gunung Meja memiliki kondisi vegetasi hutan alam yang masih cukup baik, walaupun demikian, pada beberapa wilayah terlihat adanya vegetasi hutan sekunder. Kondisi tersebut terlihat di bagian pinggiran kawasan terutama pada bagian Barat dari kawasan Taman Wisata Alam Gunung Meja. Demikian halnya dengan keberadaan kebun-kebun masyarakat di pinggiran kawasan dan sarana dan prasarana yang telah dibangun terutama di dalam kawasan taman wisata alam ini.

Selain vegetasi hutan yang digolongan sebagai hasil hutan kayu, pada kawasan ini pula dijumpai jenisjenis vegetasi non kayu seperti rotan (Calamus sp.), palem (Areca sp.), bambu (Bambusa spp.), tumbuhan paku (Pteridophyta), pandan (Pandanus sp.) dan jenis-jenis anggrek seperti Dendrobium sp., Bulbophyllum sp., Spathoglottis sp. dan jenis-jenis vegetasi lainnya (Sinery, 2006). Menurut BBKSDA Papua Barat (2008); Basna (2007); Manusawai (2014) di kawasan TWA Gunung Meja diidentifikasi beberapa jenis tumbuhann bukan kayu seperti Arenga microcarpa Becc. (palem), Calamus keyensis Becc. (rotan) dan Dendrobium liniale (anggrek). Beberapa jenis dari Grophyllum pinagoides, selain itu Phalaenopsis amabilis (L.) Blume tergolong langka menurut Lembaga Ilmu Pengetahuan Indonesia (LIPI).

Pada beberapa wilayah terlihat adanya asosiasi vegetasi hutan yang menunjukkan adanya variasi jenis yang menjadi karakteristik hutan tropis yang kaya akan jenis. Menurut Waroy (2006) bahwa kawasan Taman Wisata Alam Gunung Meja memiliki potensi tumbuhan liana yang cukup tinggi. Tercatat sebanyak 42 jenis liana dari 21 Famili diidentifikasi kawasan hutan ini yang mencakup famili Acanthaceae, Apocynaceae, Araceae, Aristholociaceae, Asclepiadaceae, Bignoniaceae, Convolvulaceae, Cucurbitaceae, Dioscoreaceaae, Fabaceae, Flagellariaceae, Geitonoplesiaceae, Gnetaceae, Lophopixydaceae, Menispermaceae, Moniamiaceae, Moraceae, Passifloraceae, 
Smilacaceae, Vitaceae dan Zygophyllaceae. Selain itu, kawasan ini juga kaya akan potensi Ficus spp pertimbangan dalam pengelolaan kawasan ini (Kandenapa, 2004).

\section{Hutan tanaman}

potensi lainnya yang dapat dipertimbangkan dalam pengelolaan Taman Wisata Alam Gunung Meja adalah potensi vegetasi hutan tanaman. Menurut Leppe dan Tokede (2008) tegakan hutan tanaman tersebar di bagian selatan kawasan TWA Gunung Meja dengan luas areal 27 ha dan ratarata potensi $20,70 \mathrm{~m}^{3} /$ ha sebagaimana terlihat pada Tabel 5 .

Menurut Leppe dan Tokede (2004), berdasarkan tingkat permudaannya di kawasan TWA Gunung Meja dapat dijumpai 101 jenis tingkat pohon, 89 jenis tingkat tiang, 147 jenis tingkat pancang dan 162 jenis tingkat anakan. Pada tingkat pohon tegakan hutan Gunung Meja didominasi oleh jenis Pometia coreacea, Pimelodendron amboinicum, Pometia pinnata, Palaquium amboinensis, Intsia bijuga, Koordersiodendron pinnatum, Antiaris toxycarya, Pterygota horsfieldia, Sterculia parkinsonii dan
Spathiostemon javensis. Rata-rata tinggi maksimum pohon penyusun struktur tumbuhan berkayu tersebut berkisar $30-40 \mathrm{~m}$.

Pada tegakan hutan tanaman ini tidak terlihat adanya stratifikasi tajuk dan terlihat adanya distribusi tajuk yang merata yang umumnya merupakan vegetasi tingkat pohon. mengingat bahwa tegakan ini merupakan hutan tanaman sehingga tidak terlihat adanya perbedaan strata tajuk secara jelas. Namun demikian, pada bawah tegakan terlihat adanya variasi jenis yang merupakan regenerasi dari jenis-jenis pada hutan tanaman maupun jenis-jenis vegetasi di sekitarnya.

\section{Tumbuhan obat}

Kawasan hutan Taman Wisata Alam Gunung Meja pula memiliki potensi tumbuhan obat yang sangat potensial. Berdasarkan hasil pengamatan di kawasan hutan ini dijumpai jenis-jenis tumbuhan obat seperti Alstonia scholaris, Artocarpus altilis, Calophyllum inophyllum Endospermum moluccanum dan berbagai jenis lainnya. Menurut Noya (2013) di kawasan Taman Wisata Alam Gunung Meja diidentifikasi 65 jenis dari 36 famili vegetasi hutan yang tergolong sebagai tumbuhan obat.

Tabel 5. Potensi Tegakan Hutan Tanaman di TWA Gunung Meja

\begin{tabular}{|c|c|c|c|c|}
\hline Jenis & $\begin{array}{l}\text { Tahun } \\
\text { Tanam }\end{array}$ & Luas (Ha) & $\begin{array}{c}\text { Jarak Tanam } \\
(\mathrm{m})\end{array}$ & $\begin{array}{l}\text { Potensi } \\
\left(\mathrm{m}^{3} / \mathrm{Ha}\right)\end{array}$ \\
\hline Tectona grandis & 1958 & 2,5 & $2 \times 3$ & 42,30 \\
\hline Pometia spp. & 1958 & 1,2 & $2 \times 3$ & 17,84 \\
\hline Koordersiodendron & & & & \\
\hline pinnatum & 1960 & 2,7 & $2 \times 5$ & 29,39 \\
\hline $\begin{array}{l}\text { Palaquium ambiinensis } \\
\text { Colophyllum }\end{array}$ & 1961 & 7,8 & $2 \times 5$ & 34,00 \\
\hline inophyllum & 1961 & 7,8 & $2 \times 5$ & 19,18 \\
\hline Tectona grandis & 1970 & 3 & $2 \times 3$ & 31,60 \\
\hline Araucaria cuningghanii & 1970 & 2 & $2 \times 3$ & 19,60 \\
\hline Jumlah atau Rata-rata & & 27 & & 20,70 \\
\hline
\end{tabular}

Sumber : Leppe dan Tokede (2004), BBKSDA Papua Barat (2008) 
Jenis-jenis yang diidentifikasi mencakup 21 jenis vegetasi tingkat pohon seperti Alstonia scholaris, Artocarpus altilis, Calophyllum inophyllum, Endospermum moluccanum dan jenis lainnya, 18 jenis liana seperti Archingelesia flava, Bauhinia acuminata, Flagellaria indica dan jenis lainnya, 13 jenis herba seperti Ageratum conyzoides, Bidens pilosa, Canna hybrida dan jenis lainnya, 11 jenis perdu seperti Dracaena angustifolia, Fagraea racemosa, Gnetum gnemon dan jenis lainnya. Selain itu juga diidentifikasi jenis tumbuhan yang digolongkan sebagai semak dan terna masing-masing Solanum torvum dan Paspalum conjugatum.

Selanjutnya disebutkan bahwa dari jumlah tersebut sebanyak 57 jenis tumbuhan diantaranya digunakan untuk mengobati 46 jenis penyakit, sedangkan 7 jenis lainnya digunakan secara umum untuk menunjang kehidupan manusia (pewarna kain, bahan untuk mencari ikan, dan penggunaan lainnya).

Secara khusus untuk tanaman hias seperti palem (Areca sp., Lycuala sp.), anggrek dan tumbuhan obat-obatan seperti Areca sp., Alstonia speciosa dan Arenga sp., merupakan potensi kawasan terkait pengembangan ekonomi masyarakat yang perlu dipertimbangkan dalam pengelolaan kawasan ini di masa mendatang.

\section{Tanaman pertanian/perkebunan}

Telah dibahas sebelumnya, bahwa selain vegetasi hutan alam, hutan tanaman juga diidentifikasi vegetasi pertanian dan perkebunan yang diusahakan masyarakat sekitar kawasan ini. Jenis-jenis tersebut diusahakan oleh masyarakat pada lahan-lahan pertanian atau perkebunan di sekitar pemukimannya sebagaimana tercantum pada Tabel 6 berikut.
Tabel 6. Tanaman Pertanian dan Perkebunan yang diusahakan oleh Masyarakat Sekitar TWA Gunung Meja

\begin{tabular}{ll}
\hline \multicolumn{1}{c}{ Jenis } & \multicolumn{1}{c}{ Nama ilmiah } \\
\hline Cokelat & Theobroma cacao \\
Jagung & Zea mays \\
Jeruk & (Citrus sp.) \\
Kacang Panjang & (Phaseolus vulgaris) \\
Keladi & (Colocasia esculenta) \\
Kelapa & (Cocos nucifera) \\
Ketimun & (Cucurbita moschata) \\
Langsat & (Lansium indicum) \\
Nangka & (Arthocarpus integra) \\
Pisang & (Musa sp.) \\
Rambutan & (Nephelium \\
& lapaceum) \\
Sawi & (Brassica juncea) \\
Ubi Jalar & (Ipomoea batatas) \\
Ubi Kayu & (Manihot utilissima) \\
\hline
\end{tabular}

Secara umum masyarakat melakukan kegiatan pertanian atau perkebunan untuk memenuhi kebutuhan hidup sehari-hari, namun demikian beberapa dari meraka mulai mengupayakan optimalisasi hasil usaha. Optimalisasi tersebut dilakukan melalui penjualan hasil usaha guna memenuhi kebutuhan keluarga dan tabungan.

\section{Fauna}

Kawasan TWA Gunung Meja juga merupakan habitat yang potensial bagi kehidupan satwa liar. Menurut Leppe dan Tokede (2004), BBKSDSA (2008) dikawasan TWA Gunung Meja dijumpai 15 jenis dari 6 kelas mamalia, 35 jenis burung (aves) dari 20 famili, 20 jenis herpetofaona (7 kadal, 3 ampibia, 9 jenis ular dan 1 jenis kura-kura).

Pada kelas mamalia (mammal) seperti babi hutan (Sus papuensis), kuskus (Phalenger orientalis, Spilocuscus maculatus), tupai (Petaurus breviceps) dan kelelawar (Nyctimene 
sp.), burung (aves) seperti elang (Heliastur indus), nuri kepala hitam (Lorius lorry) dan bayan (Elactus rotatus), reptil (reptile) seperti ular putih (Micropechis ikaheka), pyton (Chondropython sp.), biawak (Varanus salvator, $V$. prasinus), bunglon (Hypsilurus modestus.) dan jenis-jenis katak seperti Litoria sp. dan Bufo melanotictus. Selain itu dijumpai jenisjenis satwa liar dari kelas serangga (insect) seperti kupu-kupu (Paradisea spp), kumbang dan lebah terutama lebah madu seperti Apis melipera sp. dan Trigona sp.

Dari jumlah tersebut terdapat 24 jenis satwa yang merupakan pemakan daging/hewan (carnivora), 54 jenis pemakan tumbuhan (herbivora) dan 15 jenis merupakan pemakan serangga (insectifora). Menurut Sinery (2006) terdapat 2 jenis kuskus di TWA Gunung Meja masingmasing kuskus timur (Phalanger orientalis) dan kuskus totol biasa (Spilocuscus aculatus) yang keberadaannya dilindungi oleh pemerintah.

Menurut Manusawai (2014) secara khusus untuk lebah madu (Apis melipera dan Trigona sp.) dan berbagai jenis lainnya terutama jenis-jenis serangga seperti kupu-kupu dan kumbang di kawasan ini merupakan potensi kawasan terkait pengembangan ekonomi masyarakat yang perlu dipertimbangkan dalam pengelolaan kawasan ini di masa mendatang. Selain jenis-jenis satwa liar tersebut, masyarakat juga memelihara jenis-jenis hewan lain untuk menunjang kehidupannya. Jenis-jenis hewan yang dipelihara masyarakat di sekitar kawasan hutan ini meliputi anjing, ayam dan babi yang potensinya lebih sedikit.

\section{Tugu Jepang}

Tugu Jepang merupakan potensi unggulan TWA Gunung Meja yang terdapat didalam kawasan ini sebagai potensi wisata sejarah. Monumen ini merupakan tugu peringatan pendaratan dan pendudukan pasukan Jepang di wilayah Manokwari pada saat Perang Dunia II. Potensi ini menjadi daya tarik tersendiri bagi wisatawan khususnya warga negara Jepang, karena memiliki sejarah terkait perjuang bangsa ini melawan sekutu.

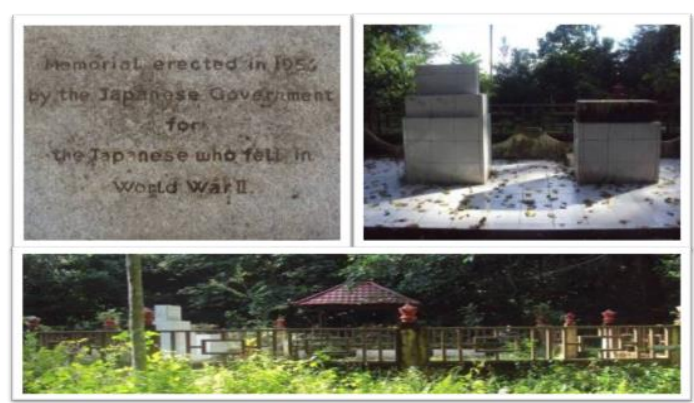

Gambar 6. Obyek Wisata Tugu Jepang

Selain obyek wisata berupa tugu, dari lokasi ini pula dapat dinikmati pemendangan Kota Manokwari dengan keberadaan laut yang indah. Saat ini kondisi Tugu Jepang sangat memprihatinkan, dan kelihatan kurang terawat dan tentunya menjadi pertimbangan dalam pengelolaan kawasan ini dimasa mendatang.

\section{Mata Air dan Potensi Air}

Berdasarkan hasil penelitian dan hasil-hasil penelitian sebelumnya diketahui bahwa di kawasan TWA Gunung Meja tidak dilintasi atau tidak dilalui adanya sungai. Kawasan ini walaupun tidak memiliki sungai, namun memiliki sejumlah mata air yang cukup potensial. Diketahui bahwa sekitar 30 mata air berupa goa- 
goa dan mata air tersebar di dalam dan sekitar kawasan ini (Zieck, 1960 dalam Manusawai, 2014). Menurut laporan Perusahaan Daerah Air Minum (PDAM) Kabupaten Manokwari, sebanyak 12 mata air yang dijadikan sumber pasokan air bagi masyarakat kota Manokwari dan 7 diantaranya terdapat di dalam dan sekitar TWA Gunung Meja. Mata air ini sebagian besar berada di kaki lereng sisi sebelah selatan kawasan taman wisata alam ini.

Pasokan air yang bersumber dari mata air di wilayah Gunung Meja tersebut menyumbang sekitar 10,30\% dari total pasokan sumber air yang dimanfaatkan oleh PDAM Manokwari. Dari jumlah tersebut, jika rata-rata jumlah air tersimpan dibawah tegakan hutan tanaman tersebut diasumsikan sama dengan di bawah tegakan alam di Gunung Meja yang luas 460,16 ha, maka kemampuan dalam tanah di hutan Gunung Meja menyimpan air sebesar 1.648.134 ton. Inilah jumlah cadangan air yang akan mengisi mata air dan sumur penduduk di musim kemarau pada daerah-daerah yang lebih rendah (Liborang, 2006).

Menurut BBKSDA Papua Barat (2008) bahwa struktur geologi kawasan hutan Taman Wisata Alam Gunung Meja termasuk dalam formasi Manokwari, yang dicirikan oleh adanya daerah tebing karang yang memiliki goa. Goa-goa karang ini yang merupakan reservoir air tanah yang kemudian menyalurkan air (sumber mata air). Terdapat 23 mata air yang dimanfaatkan oleh masyarakat di sekitar kawasan bahkan masyarakat di sekitar kota Manokwari pada umumnya. Ditemukan 19 goa alam dan 4 di antaranya berukuran besar dan menyebar di sepanjang tebing karang pada sisi Selatan kawasan ini.
Berdasarkan data hasil penelitian dan data sekunder yang digunakan, diketahui bahwa TWA Gunung Meja memiliki potensi mata air yang cukup potensial dan tersebar di seluruh kawasan ini. Sejumlah mata air yang terdapat di kawasan ini dipergunakan oleh masyarakat dan PDAM Kabupaten Manokwari untuk keperluan sehari-hari. Menurut Basna (2007); BBKSDA Papua Barat (2008) terdapat 44 (empat puluh empat) mata air yang masih aktif digunakan oleh masyarakat, yaitu tujuh mata air dikelola oleh pihak pemerintah, satu mata air dikelola dan dimanfaatkan oleh Korem 1703 Manokwari dan tiga puluh enam dimanfaatkan oleh masyarakat. Pemanfaatan air oleh masyarakat dilakukan dengan menggunakan bak penampung dan selanjutnya dialirkan menggunakan selang ke rumahrumah masyarakat. Pasokan mata air tersebut diperkirakan menyumbangkan $10,30 \%$ dari total pasokan sumber mata air yang dimanfaatkan oleh PDAM Manokwari (BBKSDA Papua Barat, 2008).

Pemanfaatan air bersih dari kawasan TWA Gunung Meja sebenarnya telah dilakukan sejak tahun 1957-an (zaman Belanda). Pada saat itu PDAM Manokwari mengusulkan untuk membangun instalasi air bersih dan bak penampungan. Setidaknya ada 7 bak penampungan air yang telah dibangun oleh Belanda, yaitu 3 bak terletak di Kampung Ambon Atas, 2 bak di sekitar KOREM 1703, 1 bak daerah Brawijaya dan 1 bak di daerah Fanindi (Bukit Doa). Semua bak air tersebut saat ini masih aktif dan dalam kondisi bagus. 

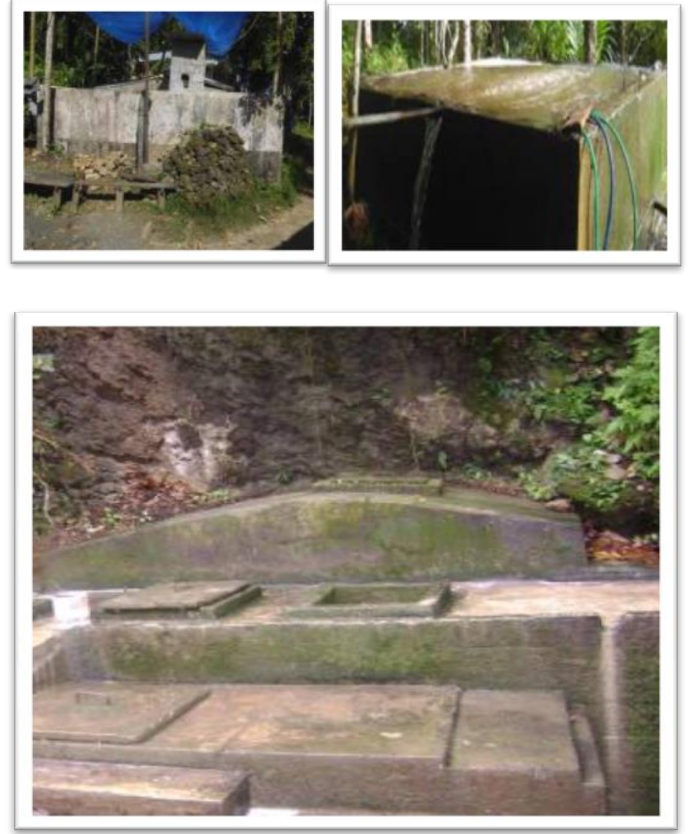

Gambar 7. Bak Air Peninggalan Belanda yang Masih dimanfaatkan

Pada saat ini keberadaan bak tersebut dapat dimanfaatan sabagai obyek daya tarik wisata yang potensial. Hal ini karena bak-bak tersebut mengandung muatan sejarah serta memiliki bentuk yang unik. Untuk memudahkan menjangkau bak-bak tersebut dapat melalui ruas jalan setapak/jalan trail yang menghubungkan lokasi bak air dengan obyek wisata lainnya seperti Goa Jepang, Tugu Jepang termasuk hutan alam, dan hutan tanaman. Menurut Liborang (2004) diketahui bahwa beberapa sumber mata air yang sangat potensial untuk dijadikan alternatif mata air bagi kebutuhan masyarakat di Kota Manokwari yaitu Mata Air Indoki I, Mata Air Indoki II, Mata Air Kwawi I dan Mata Air Kwawi III. Apabila dilihat dari jumlah pelanggan PDAM sampai tahun 2004 yang memakai air pada tujuh mata air tersebut sebanyak 262 KK dengan kapasitas total pemakaian per hari sebesar $91,8 \mathrm{~m}^{3} /$ hari. Kapasitas total pemakaian pada periode hujan sebesar
$264,6 \mathrm{~m}^{3} /$ hari dan pada periode panas sebesar $150,12 \mathrm{~m}^{3} /$ hari dengan rata- rata kapasitas total pemakaian perhari pada kedua periode tersebut sebesar 207,36 $\mathrm{m} 3 /$ hari. Pemakaian air untuk satu keluarga perhari sebesar $1 \mathrm{~m}^{3} /$ hari, sedangkan pemakaian air untuk satu orang perhari sebesar $0,2 \mathrm{~m}^{3} /$ hari. Ditinjau dari kapasitas total pemakaian dari tahun 2002 sampai tahun 2004 secara kuantitas masih dapat terpenuhi.

Menurut Loborang (2004) debit air pada periode hujan tertinggi terdapat pada mata air Indoki I sebesar 0,0087 $\mathrm{m}^{3} /$ detik dan terendah pada mata air Kwawi II sebesar $0.0004 \mathrm{~m}^{3} /$ detik dengan rata-rata $0,0035 \mathrm{~m}^{3} /$ detik, sedangkan pada periode panas tertinggi pada mata air Kwawi I sebesar 0,0048 $\mathrm{m}^{3} /$ detik dan terendah pada mata air Indoki III sebesar $0.0001 \mathrm{~m}^{3} /$ detik dengan rata-rata $0,002 \mathrm{~m}^{3} /$ detik. Kapasitas total pemakaian perhari pada periode hujan sebesar 264,6 m3/hari dan pada periode panas sebesar 150,12 m3/hari dengan rata- rata kapasitas total pemakaian perhari pada kedua periode tersebut sebesar 207,36 m3 /hari.

\section{Goa}

Goa merupakan suatu ekosistem spesifik yang khas dan sangat penting bagi beberapa jenis organisme tertentu, sehingga dalam pengelolaannya perlu penanganan secara baik. Menurut Suyanto (2001) dalam Sinery (2013) goa merupakan salah satu ekosistem yang sangat penting bagi kelelawar karena goa merupakan habitat populasi kelelawar. Kondisi goa-goa yang ada di seluruh Indonesia saat ini beberapa sudah rusak akibat pembangunan jalan oleh pemerintah, dan dimanfaatkan pengunjung sebagai tempat wisata sehingga populasi kelelawar yang dulunya ratusan spesies namun kini hanya puluhan spesies. 


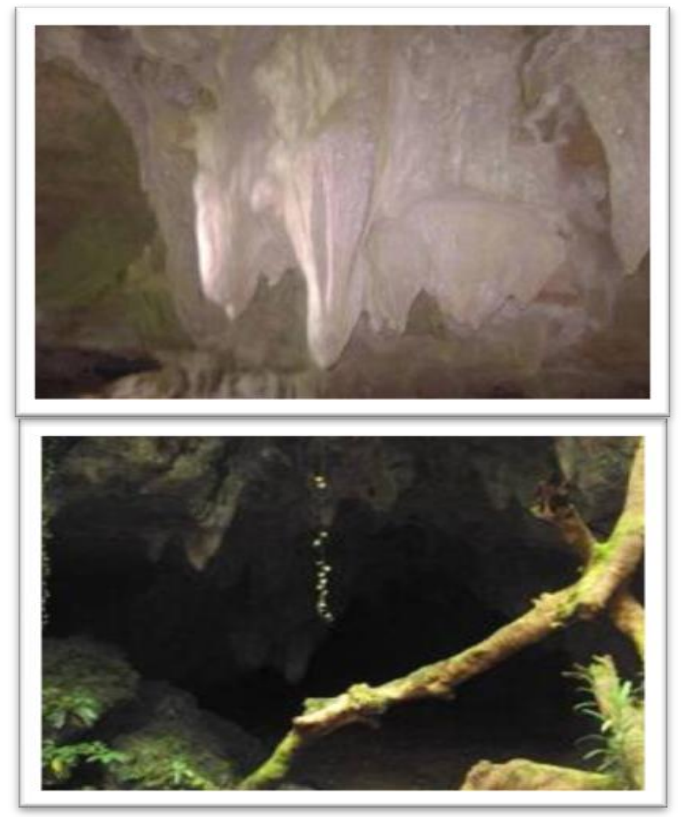

Gambar 8. Goa Alam di Kawasan TWA Gunung Meja

Kawasan TWA Gunung Meja merupakan salah satu kawasan yang memiliki potensi goa yang cukup besar. Potensi tersebut mencakup 19 goa alam dan 4 diantarnya berukuran besar dan berpotensi sebagai daya tarik wisata.
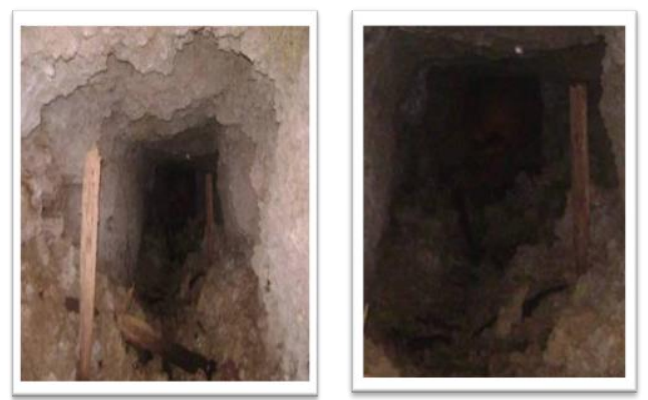

Gambar 9. Goa Jepang Di Dekat Kampung Ayambori

Selain Goa Alam di kawasan TWA Gunung Meja juga terdapat beberapa goa yang merupakan peninggalan Perang Dunia II (Goa Jepang). Goa-goa tersebut merupakan tempat persembunyian tentara Jepang dalam melawan tentara Sekutu yang sampai saat ini masih meninggalkan bekas-bekas keberadaan masa lalu.

Struktur geologi kawasan hutan wisata alam Gunung Meja yang merupakan formasi Befoor (Formasi Manokwari), yang dicirikan oleh adanya daerah tebing karang dengan goa-goa yang terbentuk secara alami. Goa-goa tersebut merupakan sungai bawah tanah yang menyimpan dan mengalirkan air yang dimanfaatkan oleh masyarakat sebagai reservoir cadangan air.

Data hasil penelitian menunjukkan, bahwa setidaknya terdapat dua goa reservoir di kawasan Gunung Meja yang dimanfaatkan sebagai reservoir bagi masyarakat di sekitar kawasan ini. Goagoa Jepang tersebut tedapat disebelah Selatan kawasan TWA Gunung Meja (dekat Kampung Ayambori).
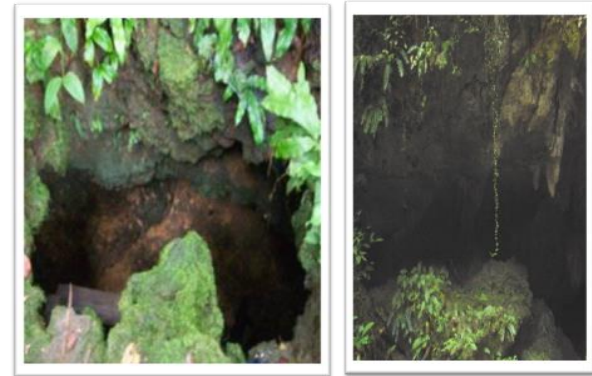

Gambar 10. Goa Reservoir Air Di Daerah Fanindi

\section{Kondisi Sosial, Ekonomi dan Budaya}

Secara umum, manusia selalu berusaha memanfaatkan sumber daya alam (natural resources) yang ketersediaannya terbatas guna memenuhi kebutuhan hidup dan meningkatkan kesejahteraannya. Pertambahan penduduk secara eksponensial cenderung mengakibatkan berkurangnya sumber daya alam, pada 
gilirannya akan berpengaruh terhadap kesejahteraan hidup manusia, sehingga dapat dipastikan akan timbul dampak negatif daripada pertumbuhan penduduk terhadap kualitas lingkungannya.

Kawasan TWA Gunung Meja secara administratif berbatasan langsung dengan 4 wilayah kelurahan, yaitu Kelurahan Amban, Kelurahan Padarmi, Kelurahan Manokwari Timur dan Kelurahan Pasir Putih. Berdasarkan data hasil penelitian diketahui bahwa jumlah penduduk di keempat kelurahan tersebut sampai tahun 2013 cukup potensial sebagaimana tercantum pada Tabel 7.

Tabel 7. Jumlah Penduduk di Sekitar TWA Gunung Meja

\begin{tabular}{lcc}
\hline \multicolumn{1}{c}{ Kelurahan } & $\begin{array}{r}\text { Kepala } \\
\text { Keluarga }\end{array}$ & $\begin{array}{c}\text { Penduduk } \\
\text { (Jiwa) }\end{array}$ \\
\hline $\begin{array}{l}\text { Kelurahan } \\
\text { Amban }\end{array}$ & 1.134 & \\
$\begin{array}{l}\text { Kelurahan } \\
\text { Pasir Putih }\end{array}$ & 715 & 4.536 \\
$\begin{array}{l}\text { Kelurahan } \\
\text { Padarni }\end{array}$ & 1.679 & 2.860 \\
$\begin{array}{l}\text { Kelurahan } \\
\text { Manokwari }\end{array}$ & 1.201 & 6.716 \\
Timur & & \\
Total & 4.729 & 18.916 \\
\hline
\end{tabular}

Dari keempat kelurahan tersebut, terdapat sembilan kampung yang berbatasan langsung atau berdekatan dengan kawasan ini, yaitu Amban, Ayambori, Aipiri, Anggori, Manggoapi, Fanindi, Brawijaya dan Kampung Ambon Atas. Etnik yang bermukim pada kampung-kampung tersebut umumnya campuran etnik asli Manokwari dan etnik pendatang. Etnik penduduk asli terutama dari suku Mole, Hatam, Sough dan Meyakh. Etnik pendatang atau urban umumnya berasal dari Sorong, Biak, Serui serta pendatang dari luar, yaitu dari Sulawesi, Ambon, Timur dan
Sumatera dan Jawa (BBKSDA Papua Barat, 2008; Manusawai, 2014).

Bentuk-bentuk interaksi di dalam dan di sekitar kawasan TWA Gunung Meja meliputi perladangan/kebun masyarakat, pengambilan kayu bakar, pengambilan hasil hutan kayu dan non kayu, perburuan, pengambilan tanah (top soil), pengambilan batu, arang, pemukiman penduduk dan bangunan fisik lainnya.

Kawasan Gunung Meja

berdasarkan filosofi budaya masyarakat Afrak, yaitu kelompok suku Hatam dan Suku Sough yang bermukim di sekitar kawasan, memandang Hutan Gunung Meja sebagai Ayamfos yang artinya dapur hidup. Ayamfos yang berarti Hutan Gunung Meja baik berupa tanah, air dan hutan yang terkandung di dalam kawasan adalah sumber penghidupan masyarakat yang perlu dijaga, dilindungi dan dimanfaatkan secara baik oleh masyarakat dalam kehidupannya. Hutan Gunung Meja merupakan "Ayamfos" sebagai tempat berkebun, sumber protein nabati dan hewani dalam pemenuhan kehidupan masyarakat sehari-hari, sumber air bersih bagi kehidupan masyarakat, tempat melakukan usaha-usaha ekonomi pertanian dan juga situs budaya "tanah larangan/tempat pamali bagi masyarakat (Manusawai, 2014).

Masyarakat yang bermukim di wilayah pemukiman Ayambori dan Fanindi sudah sangat paham akan pentingnya Hutan Gunung Meja sebagai sumber kehidupan mata air bagi kehidupannya. Berdasarkan filosofi budaya dan sumber mata air, terutama daerah hulu merupakan "tanah larangan" atau tempat pantangan (pamali) yang tidak boleh dimasuki oleh masyarakat. Namun 
perkembangan pembangunan berdampak terhadap kebutuhan lahan pertanian masyarakat di sekitar wilayah perkotaan menyebabkan kawasan ini telah dirambah, sehingga filosofi Hutan Gunung Meja telah terpolarisasi. Tanah larangan yang tidak boleh diganggu telah dimasuki oleh masyarakat luar, pengembangan dan pemanfaatan lahan secara berlebihan dilakukan secara besar-besaran. Hutan gunung Meja sebagai Ayamfos sudah mulai tidak berfungsi sebagaimana mestinya. Apabila upaya penyelamatan kawasan tidak dilakukan dengan baik, maka Hutan Gunung Meja tidak akan menjadi "Ayamfos". Hutan Gunung Meja tidak akan lagi memberikan penghidupan berupa sumber air dan hasil hutannya kepada masyarakat (BBKSDA Papua Barat, 2008; Manusawai, 2014).

Kondisi ekonomi masyarakat yang umumnya merupakan masyarakat subsisten dengan ekonomi rendah sampai sedang menjadikan ketergantungan terhadap sumber daya alam di kawasan hutan ini dan wilayah sekitar menjadi cukup tinggi. Kebutuhan pangan dipenuhi dari berladang, nelayan dan meramu hasil hutan. Masyarakat memanfaatkan berbagai sumber daya hutan seperti kayu, kulit kayu, daun, buah dan berbagai jenis sumber daya lainnya termasuk satwa liar. Masyarakat di sekitar kawasan ini umumnya mengembangkan pola-pola interaksi yang berkaitan dengan mata pencaharian dan pengelolaan lahan. Beberapa dari masyarakat di sekitar kawasan ini mengupayakan sistem pertanian tradisional yang ramah lingkungan. Budaya masyarakat meliputi penerapan sistem bercocok tanam, upacara/kesenian adat, kepercayaan dalam peristiwa-peristiwa sakral, serta budaya gotong royong yang masih dilakukan. Hasil pengamatan menunjukkan, bahwa acara adat masih dipertahankan dan dilaksanakan hingga saat ini. Pelaksanaan acara-acara tersebut terlihat misalnya melalui upacara perkawinan, kematian, penerimaan tamu dan lain sebagainya.

Sacara umum masyarakat memiliki sikap dan persepsi yang positif terkait pengelolaan TWA Gunung Meja yang mencakup upaya perlindungan, pelestarian dan pemanfaatan. Dari 185 responden yang diwawancarai sebanyak 182 responden (131 sangat setuju dan 50 setuju) atau $97,84 \%$ menyatakan persepsi positif terkait pengelolaan TWA Gunung Meja, sedangkan sisanya sebanyak 4 responden $(2,16 \%)$ raguragu dan cenderung mengarah pada penolakan terkait pengelolaan TWA Gunung Meja (Lampiran 11). Hal tersebut merupakan kondisi yang sangat baik terkait upaya pengelolaan, namun demikian perlu langkah-langkah lebih strategis mengingat respon masyarakat kapan saja dapat berubah terkait adanya inovasi atau kegiatan.

\section{b. Pemanfaatan Kawasan}

Pemanfaatan kawasan merupakan suatu proses terjadinya interaksi individu, populasi atau komunitas khususnya manusia dengan suatu habitat atau lingkungan (Sinery, 2013). Didalam konteks sumber daya alam hayati pemanfaatan kawasan didasarkan pada obyek sumber daya alam yang dimanfaatkan dan umumnya dikenal sebagai etnobiologi. Etnobiologi sendiri mengandung pengertian adanya pemanfaatan sumber daya alam hayati yang mencakup flora dan fauna. Ilmu tersebut mencakup etnobotani dan etnozoologi. 
\begin{tabular}{lrr}
\multicolumn{1}{c}{ Menurut } & Sardjono & $(2004)$ \\
etnobotani & merupakan & lingkup \\
pemanfaatan & sumber daya & alam hayati \\
yang diarahkan pada pemanfaatan & pemang \\
tumbuh-tumbuhan guna & menunjang \\
kehidupan. & Etnobotani & sendiri \\
mengandung & pengertian & adanya
\end{tabular} hubungan interaksi antara manusia dan tumbuh-tumbuhan, atau suatu studi yang menjelaskan tumbuhan dalam suatu budaya, tetapi secara khusus etnobotani sendiri dibatasi dengan berbagai penelitian dan berbagai disiplin ilmu seperti antropologi, geografi, arkeologi, ilmu bahasa dan sejarah yang semuanya mendapat perhatian dalam penelitian etnobotani.

Menurut Ford (1876), Alcron (1984) dalam Pattiselano (2007) etnozoologi merupakan kajian interaksi antara masyarakat tradisional dan pengetahuannya tentang jenis-jenis hewan dalam lingkup kehidupannya. Menurut Sinery dkk (2013) perkembangan etnobiologi dewasa ini masih terfokus pada tumbuh-tumbuhan sebagai wujud pemenuhan kebuhtuhan hidup manusia, namun akan lebih penting lagi jika ada optimalisasi khusus pemanfaatan jenis-jenis satwa liar (etnozoologi).

Telah dideskripsikan sebelumnya bahwa interkasi masyarakat dengan kawasan hutan Gunung Meja cukup tinggi. Hal tersebut terlihat dari adanya pemanfaatan sumber daya alam baik flora dan fauna maupun lahan. Berdasarkan hasil pengamatan diketahui bahwa ada beberapa kegiatan terkait pemanfaatan kawasan TWA Gunung Meja yang secara langsung maupun tidak langsung berdampak terhadap eksistensi kawasan ini sebagaimana dideskripsikan sebagai berikut:

\section{Kegiatan pertanian (ladang)}

Telah dideskripsikan sebelumnya bahwa letak kawasan yang strategis di tengah kota Manokwari yang mencakup
4 wilayah keluruhan menjadikan akses terhadap kawasan hutan ini cukup tinggi. Hal tersebut dilakukan baik melalui jalan koridor di tengah kawasan maupun dari pinggiran kawasan hutan ini. Kondisi tersebut terlihat dengan adanya areal-areal kebun atau ladang masyarakat di wilayah bagian timur (terutama di wilayah Fanindi, Brawijaya). Tidak saja pada kedua wilayah tersebut, kegiatan pertanian atau perkebunan juga dilakukan oleh masyarakat di bagian barat kawasan ini terutama di sekiar wilayah Litbang Kehutanan dan wilayah Kampung Ayambori.

Berdasarkan hasil pengamatan dan wawancara diketahui bahwa kebunkebun masyarakat di sekitar kawasan ini umumnya ditanami jenis-jenis tanaman pertanian seperti jagung, pisang, singkong, ubi jalar dan sayur-sayuran seperti kacang panjang, bayam, kangkung dan sawi termasuk tanaman buah-buahan seperti rambutan, jeruk, pepaya, kelapa dan jenis-jenis tamanan lainnya.

Ohuiwutun (1995) dalam Sinery (2006) bahwa kerusakan hutan Taman Wisata Gunung Meja akibat aktifitas masyarakat sekitar kawasan hutan ini mencapai 8,9 ha. Menurut Apriani (2003) pemanfaatan lahan Hutan Taman Wisata Gunung Meja di tahun 2002 sebesar 39,42 ha dengan intensitas $8,6 \%$, mencakup perladangan 35,32 ha (intensitas 7,68\%) dan bekas perladangan 0,34 ha (intensitas 0,09\%). Kondisi tersebut tentu saja merupakan suatu potensi terkait eksistensi kawasan dan bila tidak dikelola secara baik, maka akan terjadi degradasi terhadap kawasan hutan ini di masa mendatang. Tidak dipungkiri bahwa keberadaan kesejahteraan masyarakat adalah prioritas, namun demikian eksistensi kawasan menjadi pertimbangan mendasar dalam pengelolaan kawasan 
ini di masa mendatang. Pertumbuhan penduduk yang samakin tinggi, diikuti kebutuhan akan lahan pemukiman dan pembangunan menjadi potensi ancaman yang selayaknya sudah harus dikelola saat ini.

\section{Penebangan hutan}

Penebangan hutan merupakan salah potensi yang diidentifikasi sebagai potensi yang mempengaruhi terkait eksistensi Taman Wisata Alam Gunung Meja. Menurut Apriani (2003) penebangan Hutan di Taman Wisata Gunung Meja tahun 2002 sebesar penebangan 0,81 ha (intensitas $0,18 \%$ ). Kondisi tersebut jauh berbeda dengan kondisi saat ini yang cenderung lebih baik.

Saat ini kegiatan penebangan di kawasan TWA Gunung Meja sudah jarang dilakukan oleh masyarakat. Berdasarkan hasil pengamatan dan wawancara diketahui bahwa penebangan kayu di kawasan TWA Gunung Meja sudah jarang dilakukan bahkan dalam lima tahun terakhir. Kondisi tersebut diduga karena meningkatnya kesadaran masyarakat dan semakin meningkatnya program pengelolaan yang dilakukan oleh para pihak terkait. Kegiatan tersebut seperti kegiatan monitoring atau pemantauan yang dilakukan dan kegiatan lainnya di dalam kawasan ini.

\section{Fasilitas Umum, Pemukiman dan Pembuangan Sampah}

Selain pemanfaatan kawasan hutan TWA Gunung Meja untuk perladangan dan penebangan, pemanfaatan lahan lainnya adalah pembangunan fasilitas atau sarana dan prasarana penunjang pengelolaan. Penggunaan lain dimaksud tersebut meliputi pemanfaatan lahan terkait fasilitas jalan, jaringan listrik dan fasilitas penunjang lainnya seperti sarana telekomunikasi. Menurut Apriani (2003), pemanfaatan Hutan Taman Wisata Gunung Meja pada tahun 2002 untuk jaringan jalan, listrik dan telekomunikasi 2,95 ha atau intensitas $0,64 \%$. Hal tersebut merupakan suatu potensi penunjang pengembangan kawasan TWA Gunung Meja, namun perlu pertimbangan yang baik sehingga tidak terjadi perubahan yang besar terhadap kawasan hutan ini.

Bentuk pemanfaatan kawasan yang mengarah pada degradasi kawasan TWA Gunung Meja adalah pembangunan pemukiman masyarakat dan pembuangan sampah di dalam kawasan. Berdasarkan hasil pengamatan menunjukkan, bahwa beberapa rumah masyarakat di sekitar kawasan TWA Gunung Meja khususnya di wilayah Fanindi, Brawijaya dan Kampung Ambon Atas dibangun melewati patok atau pal batas TWA Gunung Meja yang menunjukkan bahwa rumah-rumah tersebut berada di dalam kawasan.
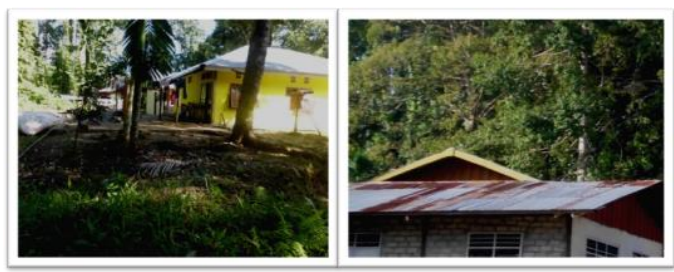

Gambar 11. Pembangunan Pemukiman di dalam TWA Gunung Meja

Menurut Manusawai (2014) sebelum tahun 2006 hanya dijumpai satu rumah yang dibangun melewati patok/pal batas TWA, namun pada tahun 2013 berkembang menjadi 4 rumah. Empat rumah tersebut masingmasing 1 rumah di Fanindi, 2 rumah di Brawijaya dan 1 rumah di Kampung Ambon. Hal ini tentu saja merupakan suatu potensi yang harus dikelola oleh BBKSDA Papua Barat melalui program kolaborasi yang melibatkan para pihak 
terkait. Tidak saja pembangunan rumah yang makin meningkat, pembuangan sampah di dalam kawasan TWA Gunung Meja juga menjadi suatu ancaman yang serius terhadap kawasan hutan ini. Berdasarkan hasil pengamatan diketahui bahwa dijumpai 25 lokasi pembuangan sampah di kawasan ini. Penyebaran sampah (sampah padat) tersebut umumnya di sepanjang jalan koridor dalam kawasan dari arah utara (perumahan dosen Unipa) sampai perumahan pemda (Perumahan Sarina) dengan potensi yang semakin sedikit ke arah tengah kawasan.

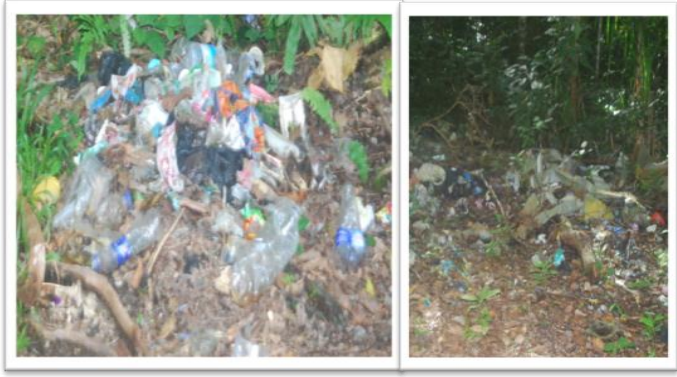

Gambar 12. Kondisi Sampah di TWA Gunung Meja

Menurut Kondororik (2012) bahwa ada 30 lokasi pembuangan sampah padat di TWA Gunung Meja, mencakup 7 jenis sampah (plastik, kertas, logam/baja/senk/aluminium, $\mathrm{kaca} / \mathrm{mika} /$ porselin, tekstil, karet/kulit dan lain sebagainya). Disebutkan juga bahwa tumpukan sampah padat dari 30 tumpukan tersebut seluas $2.054 \mathrm{~m}^{2}$ $(0,2054 \mathrm{Ha})$ atau $0,4 \%$ luas TWA Gunung Meja dengan nilai ekonomi untuk vegetasi yang rusak atau terganggu akibat timbunan sampah sebanyak 1,8 Ton pada areal seluas 0,21 Ha adalah sebesar Rp. 73.479.669 (Tujuh puluh tiga juta empat ratus tujuh puluh sembilan ribu enam ratus enam puluh sembilan rupiah).

\section{c. Strategi Pengelolaan Taman Wisata Alam Gunung Meja}

Berdasarkan pembahasan sebelumnya diidentifikasi sejumlah kondisi atau potensi Taman Wisata Alam Gunung Meja yang meliputi komponen fisik, komponen biologi dan komponen sosial ekonomi dan budaya yang dapat dioptimalkan melaui penataan kawasan (pembuatan blok pengelolaan). Hal tersebut tentunya merupakan suatu kebijakan yang perlu mendapat perhatian badan pengelola dan harus dukungan semua stakeholder.

Kebijakan dimaksud mempertimbangkan bahwa program pengelolaan kawasan yang didasarkan pada SK Menteri Kehutanan No. 91 /Menhut -II/2012 tentang Penetapan Kawasan Hutan Taman Wisata Alam Gunung Meja Distrik Manokwari Barat Dan Manokwari Timur, Kabupaten Manokwari, Provinsi Papua Barat Seluas 462,16 ha (Empat Ratus Enam Puluh Dua Enam Belas Hektar) kenyataannya telah mengalami perubahan sehingga perlu upayakan kebijakan baru sebagai berikut:

\section{Pembentukan Blok Pengelolaan}

Arahan pengelolaan berdasarkan blok pengelolaan sesuai potensi kawasan mencakup blok perlindungan, blok pemanfaatan dan blok penyangga. Acuan zonasi yang dikembangkan dalam pengelolaan dan pengembangan kawasan Taman Wisata Alam Gunung Meja adalah sebagai berikut.

\section{1). Blok Perlindungan}

Areal yang diarahkan sebagai blok perlindungan merupakan areal hutan TWA yang tidak mengalami perubahan akibat akitivitas manusia maupun alam. Berdasarkan Peraturan Menteri Kehutanan No. P. 56 /MenhutII/2006 (tentang Pedoman Zonasi Taman Nasional) diketahui bahwa 
kawasan inti/perlindungan merupakan kawasan yang mempunyai kondisi alam baik biota ataupun fisiknya masih asli dan tidak atau belum diganggu oleh manusia yang mutlak dilindungi, berfungsi untuk perlindungan keterwakilan keanekaragaman hayati yang asli dan khas.

Arahan areal blok perlindungan mencakup hutan alam dan areal sumber mata air dan goa-goa alam maupun buatan serta daerah berkelerangan > $45 \%$. Blok ini dimulai dari arah utara (batas arboretum) menuju arah selatan sampai batas jalan menuju Kampung Ayambori dan dari bagian timur (batas jaringan listrik) menuju barat sampai batas kebun-kebun masyarakat (blok pemanfaatan). Luas areal blok ini kurang lebih 325,437 ha atau 66,36\% dari luas kawasan. Blok ini diharapkan menjadi kawasan yang potensial untuk dilindungi dari semua bentuk kegiatan.

\section{2). Blok Penyangga (Buffer Zona)}

Areal yang diarahkan sebagai blok penyangga (buffer zona) kawasan TWA Gunung Meja adalah areal yang berfungsi menunjang eksistensi blok inti dan berbatasan dengan blok pemanfaatan. Areal blok penyangga merupakan areal aktivitas kebun/ladang dan areal bekas kebun. Areal dimaksud tersebut sebagian besar terdapat di bagian selatan, bagian barat dan wilayah bagian timur kawasan TWA. Arahan blok ini seluas 104,42 atau $22,59 \%$ dari luas kawasan dan membentang dari batas pinggiran blok perlindungan sejauh 100 - 250 meter menuju blok pemanfaatan. Selain areal kegiatan kebun/ladang dan areal bekas kebun/ladang areal yang diarahkan sebagai blok penyangga adalah arboretum. Areal tersebut terdapat di bagian utara, bagian barat dan sebagian di sepanjang jalan menuju arah selatan serta sebagian lagi di bagian selatan kawasan TWA. Blok ini diupayakan secara ekologis menunjang pengembangan blok perlindungan dengan kegiatan revegetasi pada lahanlahan yang terbuka.

\section{3). Blok Pemanfaatan}

Arahan blok pemanfaatan merupakan suatu konsekwensi dari pemanfaatan lahan yang telah dilakukan dan belum diakomir didalam SK Menhut No. 91 /Menhut -II/2012 tentang Penetapan Kawasan Hutan Taman Wisata Alam Gunung Meja Distrik Manokwari Barat Dan Manokwari Timur, Kabupaten Manokwari, Provinsi Papua Barat Seluas 462,16 (Empat Ratus Enam Puluh Dua Dan Enam Belas Perseratus Hektar). Pengelolaan blok ini diupayakan agar memberi ruang bagi masyarakat (khususnya dalam kawasan) untuk terlibat sebagai unit pengelola guna mengembangkan potensi khususnya potensi penunjang kegiatan wisata dan secara langsung mengurangi potensi ancaman.

Blok pemanfaatan diarahkan untuk kegiatan-kegiatan pemanfaatan lahan yang dilakukan oleh masyarakat dan kegiatan pembangunan fasilitas umum. Kegiatan dimaksud meliputi jalan koridor, areal lokasi jaringan listrik, areal sarana telekomunikasi, areal potensi wisata meliputi tugu jepang dan goa alam dan buatan yang akan dikembangkan untuk menunjang pengembangan wisata sebagai kegiatan utama dalam program pengelolaan kawasan. Selain itu diupayakan untuk melakukan pengembangan pertanian intensif melalui Kampung Organik untuk meningkatkan ekonomi masyarakat. Secara teknis pengembangan kegiatan dimaksud akan dilakukan secara kolaborasi dalam rangka mengembangan ekonomi masyarakat dan menjaga eksistensi 
kawasan. Upaya tersebut akan direncanakan sebagai program kerja yang akan dikoordinir secara langsung oleh BBKSDA sebagai lembaga teknis berwenang (pengelola) dalam pengelolaan Tamn Wisata Alam Gunung Meja.

Luas blok pemanfaatan kurang lebih 51,06 ha atau $11,05 \%$ dari luas kawasan TWA Gunung Meja, sebagaimana terlihat pada Gambar 29. Blok ini diharapkan untuk tidak mengalami perubahan yang semakin besar, sebaliknya diupaayakan agar tetap dipertahankan dengan mengoptimalkan semua input produksi dalam pengembangan komiditi yang akan dikembangkan oleh masyarakat.

\section{Penyusunan Program Kegiatan Berdasarkan Blok Pengelolaan}

Menurut Sinery (2013) legalitas pengelolaan kawasan konservasi sebenarnya mencakup tiga hal pokok, yaitu perlindungan sistem penyangga kehidupan, pengawetan keanekaragaman jenis tumbuhan dan satwa beserta ekosistemnya dan pemanfaatan secara lestari sumber daya alam beserta ekosistemnya. Beranjak pernyataan tersebut, penyusunan program pengelolaan TWA Gunung Meja sesuai fungsi kawasan dilakukan melalui beberapa kegiatan, sebagai berikut:

a. Pembinaan habitat dan populasi flora-fauna dan ekosistem pada blok lindung, pengaturan pemanfaatan hasil hutan non kayu yang dapat dikembangkan masyarakat untuk meningkatkan nilai tambah suatu sumber daya alam yang bernilai ekonomis misalnya dengan pengembangan kampung organik pada blok pemanfaatan.

b. Pendayagunaan potensi ekowisata terutama tugu jepang, hutan alam, hutan tanaman dan goa serta jasa lingkungan terutama air untuk peningkatan ekonomi dengan tetap memperhatikan prinsip keseimbangan antara kepentingan pemanfaatan dan kelestarian alam.

c. Mengakomodasi kegiatan penelitian dan pengembangan serta kegiatan pendidikan dan latihan yang diselaraskan dengan kebutuhan dan perkembangan ilmu pengetahuan dan teknologi.

d. Peningkatan status, keterampilan dan pemahaman petugas (Polisi Kehutanan) terhadap perlindungan, pengawetan dan pemanfaatan sumber daya alam.

e. Kerjasama badan pengelola dengan perguruan tinggi terkait pendataan potensi sosial, termasuk potensi usaha guna dikembangkan untuk peningkatan ekonomi.

f. Penyuluhan dan pelatihan bagi masyarakat sekitar secara rutin dan berkesinambungan dengan menciptakan jenis-jenis usaha sehingga membantu mencarikan jalan keluar bagi ketergantungan terhadap kawasan hutan seperti kegiatan kampung organik dan kegiatan lainnya.

g. Meningkatkan program pendidikan lingkungan hidup bagi masyarakat sekitar kawasan untuk lebih meningkatkan pemahaman dan rasa memiliki terhadap kawasan.

\section{Pengawasan dan Penegakan Hukum}

1. Meningkatkan kegiatan pengawasan/pengamanan kawasan secara rutin dengan melibatkan pihak pemerintah daerah (Dinas Kehutanan), pihak keamanan dan pihak lainnya termasuk masyarakat.

2. Mengoptimalkan sarana dan prasarana termasuk tenaga dan dana guna menunjang kegiatan 
pengawasan dalam pengelolaan kawasan.

3. Mengoptimalkan kegiatan pengamanan kawasan melalui pengamanan swakarsa oleh masyarakat dengan sistem kompensasi.

4. Optimalisasi penegakan hukum melalui pemberian sanksi guna memberi efek jera terhadap pelakupalaku terkait degradasi kawasan.
5. Meningkatkan ruang partisipasi bagi para pihak dalam upaya penegakan hukum terkait penanganan kasus.

Gambaran secara ringkas tentang arahan blok pengelolaan dan kriteria pertimbangan yang digunakan dapat dilihat pada Tabel 8 .

Tabel 8. Arahan Blok, Penetapan Kriteria dan Rencana Pengelolaan

\begin{tabular}{|c|c|c|}
\hline $\begin{array}{c}\text { Blok } \\
\text { Pengelolaan }\end{array}$ & Kriteria & Rencana Pengelolaan \\
\hline $\begin{array}{l}\text { Perlindungan } \\
\text { (Lindung) }\end{array}$ & $\begin{array}{l}\text { - Hutan primer, areal sumber } \\
\text { mata air dan goa alam, goa } \\
\text { buatan, daerah berkelerangan } \\
>45 \% \text {. } \\
\text { - Mempertahankan proses } \\
\text { ekologis potensi kawasan } \\
\text { - Memiliki luas areal yang } \\
\text { cukup }(325,437 \text { ha) }\end{array}$ & $\begin{array}{l}\text { - Pembinaan habitat dan populasi } \\
\text { flora-fauna dan ekosistem } \\
\text { - Mengakomodasi kegiatan } \\
\text { penelitian dan pengembangan serta } \\
\text { kegiatan pendidikan dan latihan } \\
\text { - Peningkatan } \\
\text { pengawasan/pengamanan kawasan } \\
\text { - Pengembangan pengamanan } \\
\text { swakarsa }\end{array}$ \\
\hline $\begin{array}{l}\text { Penyangga } \\
\text { (buffer zona }\end{array}$ & $\begin{array}{l}\text { - Areal hutan yang membatasi } \\
\text { blok lindung dan blok } \\
\text { pemanfaatan } \\
\text { - Areal aktivitas kebun/ladang } \\
\text { dan areal bekas kebun } \\
\text { - Luas 104,42 ha } \\
\text { - Fungsi menunjang } \\
\text { pengembangan blok } \\
\text { perlindungan dengan kegiatan } \\
\text { revegetasi pada lahan-lahan } \\
\text { yang terbuka }\end{array}$ & $\begin{array}{lrr}\text { - Mendukung proses ekologis blok } \\
\text { lindung dan pengembangan blok } \\
\text { pemanfaatan } & & \\
\text { - Optimalisasi } & \text { kegiatan } & \text { revegetasi } \\
\text { areal-areal } & \text { yang } & \text { telah } \\
\text { dimanfaatkan } & & \end{array}$ \\
\hline Pemanfaatan & $\begin{array}{l}\text { - Areal jalan koridor, lokasi } \\
\text { jaringan listrik, areal sarana } \\
\text { telekomunikasi } \\
\text { - Areal potensi wisata meliputi } \\
\text { tugu jepang dan goa alam dan } \\
\text { buatan } \\
\text { - Luas } 51,06 \text { ha } \\
\text { - Menunjang pengembangan } \\
\text { potensi wisata dan } \\
\text { pengembangan ekonomi } \\
\text { masyarakat }\end{array}$ & $\begin{array}{l}\text { - Pendayagunaan potensi ekowisata } \\
\text { terutama tugu jepang, hutan alam, } \\
\text { hutan tanaman dan goa serta jasa } \\
\text { lingkungan terutama air } \\
\text { - Pengembangan pertanian intensif } \\
\text { (Kampung Organik) }\end{array}$ \\
\hline
\end{tabular}




\section{KESIMPULAN}

Taman Wisata Alam Gunung Meja merupakan salah satu kawasan konservasi yang secara fisik memiliki kondisi iklim, topografi, kelerengan, tanah, mata air dan air serta tutupan hutan (hutan alam dan tanaman 89,2\%) sehingga potensial untuk menunjang pengelolaan sumber daya alam baik flora, fauna, ekosistem dan kondisi sosial, ekonomi dan budaya masyarakat, namun diperhadapkan dengan sejumlah ancaman terkait eksistensi kawasan akibat letak kawasan yang berada di tengah kota Manokwari.

Potensi keanekaragaman hayati baik flora pada hutan alam yang cukup tinggi (223 jenis /100 ha), mencakup 159 jenis pohon (186 individu/ha), 149 jenis tiang (867 individu/ha), 164 jenis pancang (3.904 individu/ha) dan 177 jenis semai (32.300 individu/ha), fauna yang mencakup 15 jenis mamalia (2 jenis dilindungi), 35 jenis burung (12 jenis dilindungi), 21 jenis herpetofauna ( 8 kadal, 3 ampibia, 9 jenis ular dan 1 jenis kura-kura) dan 14 jenis insekta ( 1 jenis dilindungi) dan potensi vegetasi hutan tanaman yang mencakup 101 jenis pohon, 89 jenis tiang, 147 jenis pancang dan 162 jenis semai yang potensial menunjang pengelolaan kawasan dalam fungsi wisata, pendidikan dan penelitian serta sosial ekonomi dan budaya.

Sejumlah masyarakat dari 5 keluruhan di sekitar Taman Wisata Alam Gunung Meja dengan jumlah penduduk 18.916 jiwa (4.729 kepala keluarga) memiliki ketergantungan yang cukup tinggi dengan kawasan sebagai Ayamfos atau dapur hidup (tempat berkebun, sumber protein nabati dan hewani, sumber air bersih, tempat usaha ekonomi pertanian dan juga situs budaya, tanah larangan/tempat pamali bagi masyarakat) sehingga potensial untuk dikelola secara baik guna menunjang rencana pengelolaan kawasan.

Pemanfaatan kawasan Gunung Meja sesuai fungsinya sebagai TWA belum dilakukan secara baik akibat mekanisme pengelolaan yang bersifat umum (tanpa sistem blok) sehingga berdampak terhadap eksistensi kawasan akibat kegiatan pertanian, pembangunan fasilitas umum seperti jaringan listrik, sarana telekomunikasi, pembuangan sampah dan pengambilan tanah dan pembangunan rumah.

Arahan pengelolaan yang dilakukan meliputi pembentukan blok pengelolaan, pembentukan lembaga koordinasi (Mitra TWA Gunung Meja), penyusunan program kegiatan berdasarkan blok pengelolaan dan penegakan hukum.

\section{DAFTAR PUSTAKA}

Apriani S. 2003. Intensitas Penggunaan Lahan Oleh Masyarakat Pada Hutan Wisata Gunung Meja. Skripsi Sarjana Kehutanan Fakultas Kehutanan Universitas Papua, Manokwari

Annurrahim. 2009. Optimalisasi Peran Para Pihak Dalam Pengelolaan Kawasan Konservasi (Studi Kasus Taman Nasional Kutai). Tesis S2 Program Pasca Sarjana Ilmu Lingkungan Universitas Mulawarman, Samarinda

Badan Meteorologi dan Geofisika Manokwari, 2014. Keadaan Iklim di Kabupaten Manokwari, Manokwari

Balai Besar Konservasi Sumber Daya Alam Papua Barat, 2008. Rencana Pengelolaan Jangka Panjang Taman Wisata Alam Gunung Meja Periode 2009-2028 
Kabupaten Manokwari Provinsi Papua Barat, Sorong.

Barber C.V, Matthews E, Achmaliadi R, Adi M. I.G.G, Hardiono Y.M, Kartodihardjo H, Malley F.CH, Mampioper D.A, Manurung E.G.T, Nababan A, Pangkali L.B. 2001. Potret Keadaan Hutan Indonesia. Bogor, Indonesia : Forest Watch Indonesia dan Washington D.C : Global Forest Watch.

Basna N. 2007. Pengelolaan Taman Wisata Alam Gunung Meja Kabupaten Manokwari Provinsi Irian Jaya Barat. Tesis Program Pasca Sarjana Universitas Gajah Mada, Yogyakarta.

Hidayat. 2006. Potensi Konflik Pemerintahan Pusat Dan Daerah Dalam Pengelolaan Taman Nasional, Era Otonomi Daerah. Jakarta; LIPI Press

Kandenapa L, (2004). Jenis - Jenis Beringin (Ficus spp) Pada Kawasan Taman Wisata Alam Gunung Meja Manokwari. Skripsi Sarjana Kehutanan Fakultas Kehutanan Universitas Papua, Manokwari.

Kondororik M, (2012). Karakteristik Sampah Padat dan Nilai Ekonomi Degradasi Lingkungan Akibat Sampah Pada Kawasan Taman Wisata Alam Gunung Meja Manokwari. Tesis Magister Lingkungan Universitas Negeri Papua

Leppe Daud dan Tokede M.J. 2006. Potensi Biofisik Kawasan Hutan Taman Wisata Alam Gunung Meja. Balai Penelitian dan
Pengembangan Kehutanan Papua dan Maluku, Manokwari

Liborang A.S.T, 2004. Debit Air Pada Tujuh Mata Air di Sekitar Kawasan Hutan Wisata Gunung Meja Kabupaten Manokwari. Skripsi Sarjana Kehutanan Universitas Papua, Manokwari. Skripsi Sarjana Kehutanan Fakultas Kehutanan Universitas Papua, Manokwari

Lekitoo K, Matani O.M, Rewetwa H dan Heatubun C.H. 2008. BuahBuah Yang Dapat Dimakan. Seri Keanekaragaman Flora Hutan Taman Wisata Alam Gunung Meja. Balai Penelitian Kehutanan Manokwari.

Manusawai J. 2014. Strategi Pengelolaan Taman Wisata Alam Gunung Meja Kabupaten Manokwari Provinsi Papua Barat. Disertasi Doktor Kehutanan, Program Pascasarjana Universitas Mulawarman, Samarinda.

Muller-Donbois, D and H.Ellenberg (1974). Aims and Method of Vegetation Ecology. Jhon Willey and Soons, Canada.

Noya J. 2013. Tumbuhan Obat Di Hutan Taman Wisata Alam Gunung Meja Kabupaten Manokwari Provinsi Papua Barat. Skripsi Sarjana Kehutanan Fakultas Kehutanan Universitas Papua, Manokwari

Odum, P. 1993. Dasar-dasar Ekologi. Edisi Kedua. Gajah Mada Univ. Press, Yogyakarta

Pattiselanno F, 2007. Perburuan Kuskus (Phalangeridae) oleh Masyarakat 
Napan di Pulau Ratewi, Nabire Papua. Biodiversitas 8 (4):274278.

Peday, H.F.Z. 2009. Kajian Pola Sebaran Spasial dan Keanekaragaman Jenis Vegetasi Pada Daerah Tangkapan Air Taman Wisata Alam Gunung Meja. Tesis Magister Sains. Institut Pertanian Bogor.

Sinery, A. 2006. Jenis Kuskus di Taman Wisata Gunung Meja Kabupaten Manokwari. Biodiversitas 7 (2):175-180.

Sinery A. 2013. Strategi Pengelolaan Populasi Kuskus (Spilocuscus maculatus) di Pulau Numfor Provinsi Papua. Disertasi Program Doktor Ilmu Kehutanan Fakultas Kehutanan Universitas Mulawarman, Samarinda.

Sinery A., Chandradewana Boer dan Wartika Rosa Farida, 2013. Population Dynamics of Cuscus In Tourist Island of Ahe, District of Nabire, Papua. Biodiversitas Volume 14 (2) 95-100

Soerianegara, I. dan A. Indrawan. 1983. Ekologi Hutan Indonesia. Fakultas Kehutanan. IPB, Bogor

Soegianto. 1994. Ekologi Kuantitatif: Metode Analisis Populasi dan Komunitas. Usaha Nasional, Surabaya.

Wahyudi M.T, 2004. Penambahan Serasah Pada Tanah Top Soil Sebagai Media Persemaian Matoa (Pometia Coreacaeae Raldk) Asal Cabutan Alam. Skripsi Sarjana Kehutanan Universitas Negeri Papua, Manokwari.
Waroy, H. 2006. Keragaman Jenis Tumbuhan Liana di Taman Wisata Alam Gunung Meja Manokwari. Skripsi Sarjana Kehutanan Fakultas Kehutanan Universitas Negeri Papua. Manokwari.

Wiratno, Indriyo, D., Syarifuddin, A., Kartikasari, A., 2001. Berkaca Di Cermin Retak: Refleksi Konservasi dan Implikasi Bagi Pengelolaan Taman Nasional. Jakarta: The Gibbon Foundation, PILI-NGO Movement 